\title{
Geologic Map of the Death Valley ground-water model area, Nevada and California
}

By Jeremiah B. Workman, Christopher M. Menges, William R. Page, Emily M. Taylor, E. Bartlett Ekren, Peter D. Rowley, Gary L. Dixon, Ren A. Thompson, and Lauren A. Wright

Prepared in cooperation with the Nevada Operations Office,

National Nuclear Security Administration,

U.S. Department of Energy

(Interagency Agreement DE-A108-96NV11967)

Pamphlet to accompany

Miscellaneous Field Studies MF-2381-A

2002

U.S. Department of the Interior

U.S. Geological Survey 


\section{Contents}

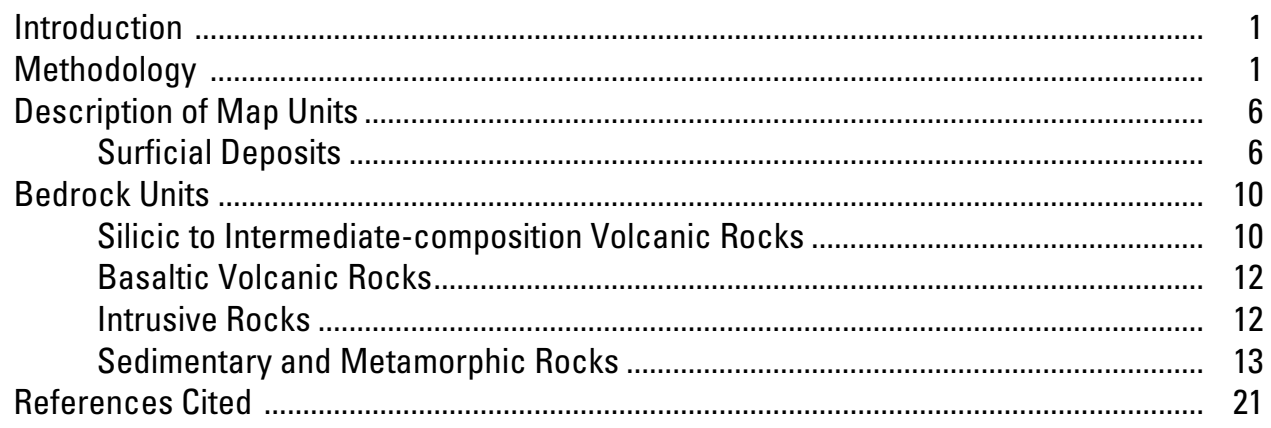

\section{Figures}

1. Index of mapping sources

2. Distribution of GPS-located field observation points used in calibrating Quaternary mapping over study area.

\section{Tables}

1. Correlation table of Upper Tertiary and Quaternary surficial units in the geologic map of the Death Valley ground-water model area and other stratigraphic sequences in and adjoining the Death Valley area

2. Summary of selected surficial deposit units mapped in Death Valley ground-water model area 


\section{Introduction}

The purpose of this map is to provide the surface expression of the geology in the Death Valley ground-water model area to be incorporated initially into a 3-D geologic framework model and eventually into a transient ground-water flow model by the U.S. Geological Survey (D'Agnese, 2000; D'Agnese and Faunt, 1999; Faunt and others, 1999; and O'Brien and others, 1999). This work has been conducted in collaboration with the U.S. Department of Energy in order to assess regional ground water flow near the Nevada Test Site (NTS) and the potential radioactive waste repository at Yucca Mountain. The map is centered on the NTS and its perimeter encircles the entire boundary of the numerical flow model area, covering a total area of $57,000 \mathrm{~km}^{2}$. The physiography, geology, and tectonics of the model area are extremely complex (Hunt and Mabey, 1966; Stewart, 1980; Jennings, 1994; Slate and others, 2000; Wright and others, 1999b). The northern and eastern part of the area includes typical Basin and Range topography consisting of north-trending block-faulted ranges and intervening valleys. The central part contains diverse ranges, plateaus, basins, and alluvial flats (for example, the NTS volcanic highlands and Amargosa Valley). The rugged ranges and deep basins of the Death Valley region in eastern California are characteristic of the topography of the southern and western parts of the map area. The map spans numerous tectonic subdivisions of the Great Basin. Deformation includes several generations of upper Paleozoic to Mesozoic thrust faulting that have been dismembered by extensive regional Tertiary to Quaternary normal and strike-slip faults. Much of this extensional and translational deformation is active today, with rates and amounts that vary from low to moderate in the central, eastern, and northern parts of the study area in southern Nevada, to very high in the southwestern and western parts in eastern California. For detailed discussion of the tectonic framework of the map area, the reader is referred to Workman and others (2002).

\section{Methodology}

This geologic map of the Death Valley ground-water model area involves the compilation of geologic data taken from many sources (figure 1). Cenozoic volcanic and sedimentary rocks are compiled and divided into major regional units based upon their isotopically determined time ranges combined with general petrographic characteristics evident in thin-section analyses. These units follow the mapping strategy of regional ash-flow tuff sheets in Ekren and others (1977), except in the Nevada Test Site area where more detailed Cenozoic stratigraphy was maintained according to Slate and others (2000). Ash-flow stratigraphy is from Mackin (1960), Cook (1965), Williams (1967), Ekren and others (1971), Anderson and Rowley (1975), Best and others (1989a, b; 1993), Page and Dixon (1994), Sawyer and others (1994), Rowley and others (1994, 1995), Scott and others (1995a, b), and Warren and others (1998). Mesozoic, Paleozoic, and Proterozoic units and their thicknesses were compiled mainly from Slate and others (2000), Albers and Stewart (1972), Burchfiel and others (1983a, b), Page and others (in press), Cornwall (1972), Jennings (1961), Jennings and others (1962), Kleinhampl and

Ziony (1985), A. Jayko (unpublished mapping, 1990), Snow (1992), Strand (1967), Streitz and Stinson (1974), Wright and others (in press), and P. Guth and J. Yount (unpublished mapping, 1994). Unit thicknesses are not given for volcanic rocks because of the extreme lateral variability in thicknesses that are commonly observed in volcanic units within the map area.

In contrast to the bedrock units, the compilation of upper Tertiary to Quaternary surficial units is based on new interpretive mapping supported by reconnaissance field observations (figure 2). Surficial units were identified and compiled on rectified Landsat 5 Thematic Mapping (TM) image maps at 1:100,000-scale, and incorporated into the map and database. The TM data in these satellite image maps were specially processed to maximize the spectral discrimination of surficial deposits in arid to semiarid basins using procedures outlined in Menges and others (1999, 2000). Unit identification on the image maps was supplemented by (a) stereographic photo-interpretation of black and white high-altitude aerial photographs (nominal scale of 1:80,000), (b) calibration using field data collected at over 600 GPS-located stations in the map area (figure 2 ), and (c) variations in geomorphic characteristics derived from 30-m-DEMs using the techniques of Jayko and Pritchett (1999) and Jayko and Menges (2001). Surficial units on the map were provisionally correlated with upper Tertiary to Quaternary units identified in other studies conducted at varying scales and levels of detail in the map area. Although most of the surficial units are derived from new mapping, some existing regional-scale maps were adapted and incorporated (table 1). A number of more localized and detailed maps and reports were used for reference during map compilation in specific localities and (or) as general age control for the surficial units used in this map (Menges and others, 2001). Surficial mapping in the southern and western sections of the map were compiled at greater detail because the major Death Valley ground-water basin discharge occurs in these areas, and this part of the map contains a greater density of field control and more pre-existing detailed geologic maps and studies. Refer to Menges and others (2001) for more information on methodologies and correlations of surficial map units used in this study. 


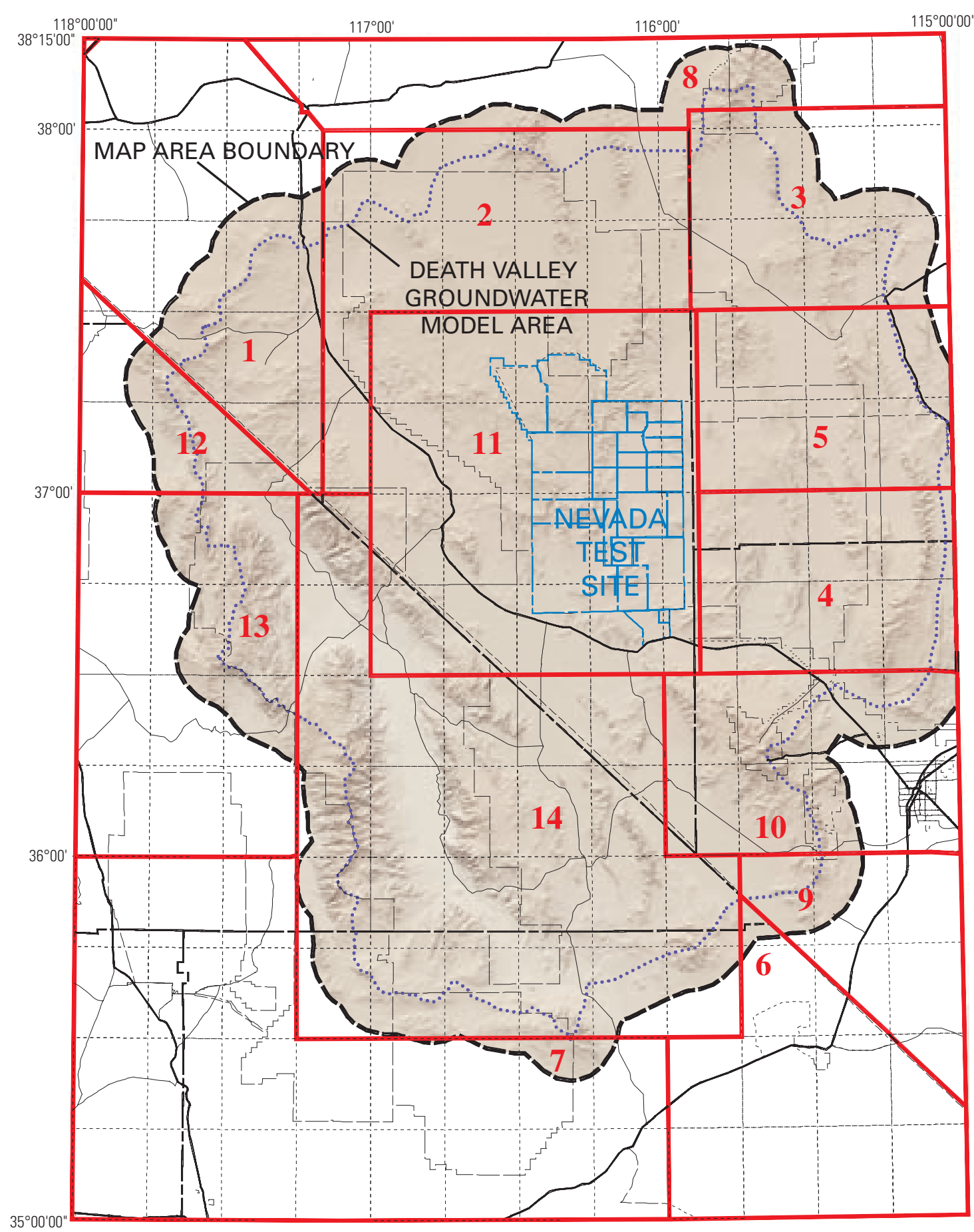

PRIMARY COMPILATION SOURCES

1. Albers and Stewart (1972)

2. Cornwall (1972)

3. Ekren and others (1977)

Tschanz and Pampeyan (1970)

4. P. Guth and J. Yount (unpublished mapping, 1994)

5. A. Jayko (unpublished mapping, 1990)

6. Jennings (1961)

7. Jennings and others (1962)
8. Kleinhampl and Ziony (1985)

9. Longwell and others (1965)

10. Page and others (in press)

11. Slate and others (2000)

12. Strand (1967)

13. Streitz and Stinson (1974)

14. Wright and others (in press)

Figure 1 (above and following page). Index of mapping sources. Primary compilation sources are shown on the figure above and all secondary, more detailed and updated sources are listed by region on the following page. 


\section{SECONDARY COMPILATION SOURCES}

1.

McKee (1985)

Reheis (1992)

Ross (1967)

2.

Ekren and others $(1971 ; 1973 ; 1976)$

Gardner and others (1980)

Klinger and Piety (1996)

Klinger and Sarna-Wojcicki (2001)

Moring (1986)

3.

E. Ekren and P. Rowley (unpublished mapping, 2000)

4.

Ekren and others (1977)

Guth (1980)

Longwell and others (1965)

Tschanz and Pampeyan (1970)

5.

Ekren and others (1977)

Tschanz and Pampeyan (1970)

6.

B. Burchfiel and G. Davis

(unpublished mapping, 1992)

8.

Ekren and others $(1971 ; 1973 ; 1976)$

9.

B. Burchfiel (unpublished mapping, 1971)

Carr and Pinkston (1987)

10.

Abolins (1999)

B. Burchfiel (unpublished mapping, 1971)

Burchfiel and others $(1974 ; 1983 a, b)$

Lundstrom and others (1998; in press)

Maldonado and Schmidt (1990)

11.

Barnes and others (1982)

Burchfiel (1965)

Hay and others (1986)

Machette and others (1999)

Machette, Klinger, and Knott (2001)

Potter and others (in press)

Sarna-Wojcicki and others (2001)
12.

Klinger and Sarna-Wojcicki (2001)

McKee (1985)

Moring (1986)

Reheis (1992)

Ross (1967)

Sarna-Wojcicki and others (2001)

13.

Burchfiel (1969)

Hall (1971)

Klinger and Peity (1996)

Klinger and Sarna-Wojcicki (2001)

McAllister (1956)

Ross (1967)

Sarna-Wojcicki and others (2001)

Snow and Lux (1999)

Stone (1984)

14.

Abolins (1999)

Beratan and others (1999)

Brady (1986)

Brady and Troxel (1999)

B. Burchfiel and G. Davis (unpublished mapping, 1992)

Burchfiel and others (1983a, b)

Butler and others (1988)

Calzia and others (2000)

Cemen and others (1999)

Denny (1965)

Denny and Drewes (1965)

Drewes (1963)

Hall and Stephens (1963)

Hay and others (1986)

Hillhouse (1987)

Hunt and Mabey (1966)

Klinger and Peity (1996)

Klinger and Sarna-Wojcicki (2001)

Knott $(1998 ; 1999)$

Machette, Klinger, and Knott (2001)

Machette, Menges, and others (2001)

McAllister (1970)

McKittrick (1988)

D. Miller and J. Yount

(unpublished mapping, 2000)

Morrison (1999)

Prave and McMackin (1999)

Sarna-Wojcicki and others (2001)

Snow and Lux (1999)

Stone (1984)

Taylor (1993)

Troxel (1986)

Troxel and Butler (1986a, b)

Wagner and Hsu (1987)

Wright and Troxel $(1984 ; 1993)$

Wright and others (1999a) 


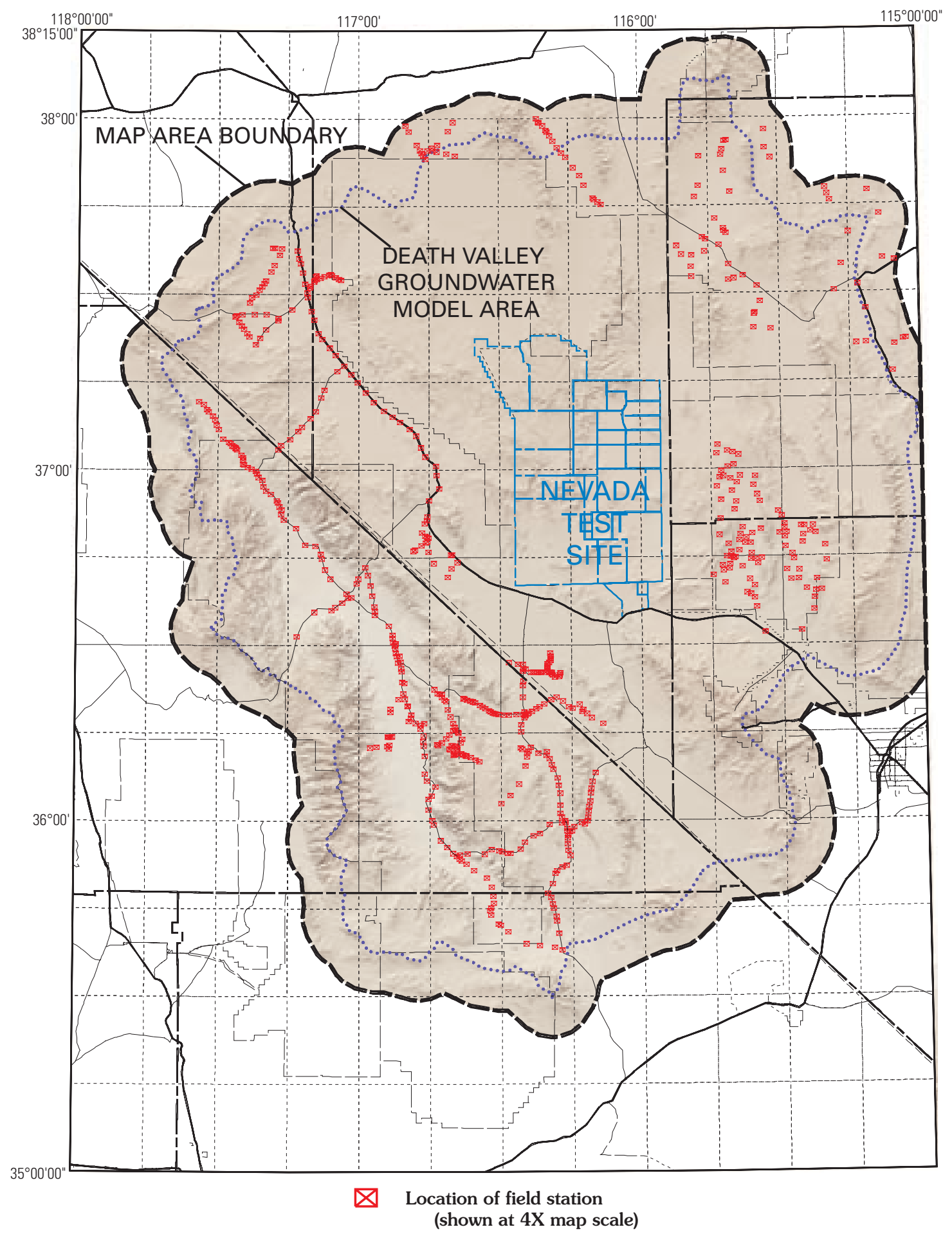

Figure 2. Distribution of GPS-located field observation points used in calibrating Quaternary mapping over study area. 
Table 1. Correlation table of upper Tertiary and Quaternary surficial units in the geologic map of the Death Valley ground-water model area and other stratigraphic sequences in and adjoining the Death Valley area. Only correlations with regional-scale mapping projects which were directly incorporated into the geologic map of the Death Valley ground-water model area are included.

[First column from left includes surficial units for Death Valley ground-water model area at regional $(1: 250,000)$ scale. The next five columns to right are Quaternary surficial units from five mapping projects both published and in progress that were incorporated into the Death Valley ground-water model area mapping program. Correlations on chart are based primarily on corresponding age ranges of units and only secondarily on genetic association (for example, alluvium vs. discharge deposits) to minimize effects of contrasting level of detail in various types of units among studies. Numbers in parentheses refer to minimum and maximum age estimates, in ka]

\begin{tabular}{|c|c|c|c|c|c|c|c|c|c|c|c|c|c|c|}
\hline $\begin{array}{r}\text { Geol } \\
\text { gl }\end{array}$ & $\begin{array}{r}\text { gic ma } \\
\text { und-w } \\
1: 25\end{array}$ & $\begin{array}{l}f \text { the Deat } \\
\text { r model a } \\
00 \text { scale }^{1}\end{array}$ & Valley & $\begin{array}{l}\text { Geologic map of the } \\
\text { Yucca Mountain } \\
\text { region- } \\
1: 50,000 \text { scale }^{2}\end{array}$ & \multicolumn{3}{|c|}{$\begin{array}{l}\text { Geologic map of the } \\
\text { Nevada Test Site- } \\
1: 100,000 \text { scale }^{3}\end{array}$} & \multicolumn{2}{|c|}{$\begin{array}{l}\text { Geologic map of the } \\
\text { Indian Springs } \\
\text { quadrangle- } \\
1: 100,000 \text { scale }^{4}\end{array}$} & \multicolumn{2}{|c|}{$\begin{array}{c}\text { Geologic map of the } \\
\text { Pahranagat } \\
\text { quadrangle- } \\
1: 100,000 \text { scale }^{5}\end{array}$} & \multicolumn{3}{|c|}{$\begin{array}{c}\text { Geologic map of the } \\
\text { Las Vegas quadrangle- } \\
1: 100,000 \text { scale }^{6}\end{array}$} \\
\hline \multirow{3}{*}{$\begin{array}{l}\text { QTau, } \\
\text { QTd, } \\
\text { QTsf, } \\
\text { QTls } \\
(0->758)\end{array}$} & \multirow[b]{2}{*}{$\begin{array}{l}\text { Qau, } \\
\text { Qe }\end{array}$} & $\begin{array}{c}\text { Qayo } \\
(5-18)\end{array}$ & $\begin{array}{l}\text { Qay, } \\
\text { Qayf } \\
\text { (Qayfe) } \\
(0-18)\end{array}$ & $\begin{array}{c}\text { Qar } \\
(0-2) \\
\begin{array}{c}\text { Qay, Qey } \\
(5-18)\end{array}\end{array}$ & \multirow{3}{*}{$\begin{array}{l}\text { QTm, } \\
\text { QTc, } \\
\text { QTu }\end{array}$} & \multirow[b]{2}{*}{$\begin{array}{l}\text { Qt, } \\
\text { Qlb }\end{array}$} & $\begin{array}{c}\text { Qay, Qey, } \\
\text { Qed, Qp, } \\
\text { Qps }\end{array}$ & \multirow{3}{*}{$\begin{array}{c}\text { Qua, Qp, } \\
\text { Qal, Qse, } \\
\text { Qls }\end{array}$} & $\begin{array}{c}\text { Qya, Qyf, Qae, } \\
\text { Qve, Qyl }\end{array}$ & \multirow{3}{*}{$\begin{array}{l}\text { Qe, Qls, } \\
\text { Qp, QTol }\end{array}$} & Qs, Qsc & \multirow{3}{*}{ QTs } & \multirow[b]{2}{*}{ Qau } & $\begin{array}{c}\text { Qay, Qayy, } \\
\text { Qayo, Qfy, } \\
\text { Qfo, Qpy, } \\
\text { Qd, Qsy, } \\
\text { Qsyy, Qse }\end{array}$ \\
\hline & & \multicolumn{2}{|c|}{$\begin{array}{l}\text { Qao, Qlc } \\
(18-758)\end{array}$} & $\begin{array}{l}\text { Qam, Qem, Qsd } \\
\quad(30-250)\end{array}$ & & & Qai, Qeo & & Qia, Qof, Qol & & $\begin{array}{l}\text { Qog, } \\
\text { QTos?, } \\
\text { QTs? }\end{array}$ & & & $\begin{array}{c}\text { Qai, Qaiy, } \\
\text { Qao, Qaoi, } \\
\text { Qso, Qscd, } \\
\text { Qsab, Qb, } \\
\text { Qby, Qbw } \\
\text { Qfw }\end{array}$ \\
\hline & \multicolumn{3}{|c|}{$\begin{array}{c}\text { QTa } \\
(500->758)\end{array}$} & $\begin{array}{c}\text { Qao } \\
(500->758)\end{array}$ & & \multicolumn{2}{|r|}{ QTa } & & $\begin{array}{l}\text { Qoa, Qof } \\
\text { QToa }\end{array}$ & & $\begin{array}{l}\text { QTog, } \\
\text { QTos, } \\
\text { QTs, }\end{array}$ & & \multicolumn{2}{|c|}{ QTa, Qb, Qbo, Qfw } \\
\hline
\end{tabular}

${ }^{1}$ Units are summarized in unit description text and in Table 2.

2 Potter and others (in press): Geologic Map of Yucca Mountain region (Surficial units mapped by E. Taylor).

3 Slate and others (2000): Digital geologic map of the Nevada Test Site (revision 4, at 1:100,000 scale). Surficial units mapped by J. Slate, M. Berry, and V. Williams, based primarily on photointerpretation on Beatty 1:100,000-scale quadrangle and the westernmost part of the Pahranagat Range and Indian Springs 1:100,000-scale quadrangles. Surficial deposits on the Pahute Mesa 1:100,000-scale quadrangle adapted from mapping of W. Swadley.

${ }^{4}$ P.L. Guth and J.C. Yount, unpublished mapping: Geologic map of Indian Springs 1:100,000-scale quadrangle (Quaternary and upper Tertiary surficial units mapped by J. Yount).

5 A.S. Jayko, unpublished mapping: Geologic map of Pahranagat 1:100,000-scale quadrangle (Quaternary and upper Tertiary surficial units included in mapping).

${ }^{6}$ Page and others (in press): Geologic map of the Las Vegas 1:100,000-scale quadrangle (Quaternary and upper Tertiary surficial units mapped by S.C. Lundstrom and J.B. Workman). 


\section{Description of Map Units}

\section{Surficial Deposits}

The surficial units in this map include some modifications from the standard types of surficial-deposit units encountered in most geologic maps. These modifications are designed to emphasize factors of potential importance to the hydrogeologic framework model for the Death Valley ground-water model, as well as infiltration-recharge and discharge elements of the model. This includes not only differentiation of specific units, such as modern channels, discharge deposits, and playas, that directly impact these factors, but also identification of generalized textural variations in deposits of potential hydrologic significance. That is, variation in grain size was approximated by differentiating where possible (a) fine-grained deposits on distal alluvial fans and alluvial plains in basin interiors from coarsegrained alluvial deposits in proximal or medial piedmont positions, and (b) fine-grained Quaternary to Tertiary basin sediments from coarse-grained alluvium of similar age range. The latter fine-grained basin sediments typically include Pleistocene to upper Tertiary basin-fill deposits of mixed lacustrine, alluvial, and (or) paludal origin exposed in some dissected basins (Hillhouse, 1987; Morrison, 1999), but locally may delineate primarily lacustrine deposits in a few closed basins (Klinger and Sarna-Wojcicki, 2001). Alluvial units are further subdivided according to more standard age categories that reflect other potentially important hydrologic characteristics such as degree of soil and pavement development, cementation, and amount of internal dissection. Colluvial deposits are not included on this map because (a) they are difficult to systematically identify on the image maps and aerial photography, (b) these deposits are commonly thin and discontinuous, especially at map scale, and (c) they typically occur in range blocks and upland areas where they would tend to obscure the hydrogeologically more significant lithology and structure of subjacent bedrock.

Specific characteristics of all units, including physiographic position, dissection, surface and weathering characteristics, and selected soil and sedimentologic properties, are summarized in table 2. General ranges of unit thickness are estimated below, but are highly variable and poorly constrained due to a lack of basal exposures of most surficial deposits in the area. The typical range of unit thickness given first applies to most surficial deposits located in basins within the central and eastern parts of the map with low to moderate rates of tectonic activity and basin subsidence in localized areas. A larger maximum range is given for some deposits to reflect their likely greater thicknesses adjacent to the fault-bounded margins of basins such as central Death Valley in the western part of the map with high rates of tectonic activity and basin subsidence.

Qc

Channel alluvium (Holocene) - Typically unconsolidated gravel, sand, and (or) silt; generally associated with zones of active to very recent surface flow and deposition. Identified on primary map only for selected major drainages that are differentiable at map scale. No significant weathering or modification of the original depositional surface. May locally include braided channel systems with small inclusions of Qay, Qayf, Qayo, and (or) Qao alluvium. Thickness varies from 0 to $30 \mathrm{~m}$, commonly from 1 to $10 \mathrm{~m}$

Qp Playa and (or) salt pan deposits (Holocene) - Variably consolidated mixtures of silt, clay, and fine sand. May contain varying proportions of secondary carbonate, gypsum, and (or) salts in very arid basins. Generally restricted to sites of active deposition in the interior of closed to poorly drained basins. No significant surface modification or soil development, although salt crusts of variable hardness and thickness may develop on surface. Deposit thickness is poorly constrained, but may vary from 1 to $10 \mathrm{~m}$ for deposits of this age; commonly underlain by poorly constrained and potentially thicker accumulations of older playa or lacustrine deposits of middle to early Holocene and Pleistocene age

Qay Young alluvium (Holocene to latest Pleistocene?) Mostly medium- to coarse-grained alluvium consisting of boulder to pebble gravel and sand, but may locally include fine-grained deposits of sand and silt. Typically unconsolidated to poorly consolidated. Commonly located in the proximal and distal positions of alluvial fans flanking basins, but also may include gravel- and sand-dominated axial drainages and fluvial terraces. Typically has no or weak soil development, no to moderate varnish development on clasts, and no to moderately modified surfaces characterized by prominent to indistinct relict depositional landforms (for example, bar and swale) with at most localized and incipient surface pavement development. Typically low surface relief related mainly to primary depositional features with at most minor dissection, although latter may increase adjacent to incised major drainages. Variable thickness commonly ranging from 0 to 20 $\mathrm{m}$; possibly as much as $30 \mathrm{~m}$ adjacent to tectonically active mountain fronts

Qayf Young fine-grained alluvium (Holocene to latest Pleistocene?)_-Mostly sand and (or) silt, locally with minor pebble gravel. Unconsolidated to poorly consolidated. Mostly associated with alluvial plains along the axial drainages of basin interiors, but may include fine-grained distal fan margins where clearly distinguishable from coarser-grained facies on aerial photography or image maps. Typically gentle surface gradients and minimal local relief. Has soil and surface characteristics similar to unit Qay, with some variation related to topographic position and finer-grained character (for example, minimal bar and swale development and fine-textured soil characteristics). Variable thickness from 0 to $10 \mathrm{~m}$; possibly as much as $30 \mathrm{~m}$ in the interiors of tectonically active subsiding basins 
Qayfe Evaporite surface crust of salts and (or) carbonate

(Holocene to latest Pleistocene?) — Localized areas

of thin evaporative surface crust of salts and (or)

carbonate overlying unit Qayf

Qayo Intermediate-age alluvium (middle Holocene to latest

Pleistocene?)-Mostly medium- to coarse-grained gravel (boulder to pebble) and sand deposits in proximal and medial basin positions. Poorly consolidated to unconsolidated. Generally has weakly developed soils, weak to moderate varnish development on clasts, and weak to moderate surface modification characterized by no to incipient pavement development with strong to weak relict bar and swale landforms. Local relief similar to that of unit Qay. Unit mapped where sufficiently large older elements of unit Qay may be differentiated on images or aerial photography and (or) are identified in field or on existing maps; otherwise unit is included within Qay. Variable thickness ranges from 0 to $10 \mathrm{~m}$, with possibly as much as $20 \mathrm{~m}$ adjacent to tectonically active mountain fronts

Qe Eolian deposits (Holocene to middle Pleistocene) Generally loose, but locally consolidated sand and silt, with local concentrations of gravel on stabilized surfaces commonly associated with buried paleosols. Typically consists of Holocene sand sheets or dune fields sufficiently thick and continuous to be mapped and (or) large individual dunes. May also locally include large relict late to mid-Pleistocene sand ramp deposits that are banked along the flanks of some ranges and may contain one or more variably developed calcic to petrocalcic relict or buried soils. Generally restricted to areas with sufficient sand accumulation to form discrete eolian landforms. Thickness of most sand sheets and dune fields vary from 0 to $10 \mathrm{~m}$, but deposits in individual large dunes and sand ramps may increase locally from 30 to $200 \mathrm{~m}$ (for example, northern Amargosa Desert and southeastern Eureka Valley)

\section{Qau Undifferentiated alluvium (Holocene to Pleis-} tocene)-Mainly used to delineate areas with intermixed Qay, Qayf, and (or) Qao deposits, with at most minor inclusions of QTa that cannot be depicted individually at map scale. Generally consists of various alluvial units of recent to middle Pleistocene age that individually comprise from $20 \%$ to $80 \%$ of area, with at most $5-10 \%$ inclusions of unit QTa. Commonly used on piedmonts with complex suites of alluvial deposits, or along drainages with narrow suites of terraces or inset surfaces, within that age range

\section{QTau Undifferentiated older alluvium (Holocene to latest}

Tertiary) - Mainly used to delineate areas of mixed Qay, Qayf, Qayo, Qao, QTa or QTsf units that are too small or too complexly intermingled to depict individually at map scale. Commonly identified where complex suites of deposits of widely mixed ages are located in proximal piedmonts or range-front embayments, interiors of dissected basins, or small narrow intramontane valleys or basins. In contrast to unit Qau, older QTa and QTsf comprise a significant component of unit QTau (commonly $>10-20 \%$ of unit area). Also used to indicate areas where one or more of the Quaternary or Quaternary and Tertiary deposits listed above are complexly intermingled with dissected tracts of unconsolidated to poorly consolidated Tertiary sediments in patterns too complex or small to discriminate individually at map scale

QTd Deposits associated with modern or past groundwater discharge (Holocene to late Tertiary) Typically fine-grained deposits of fine sand, silt, and mud, but may locally include dense crystalline deposits of limestone or travertine. Variably indurated, from unconsolidated to cemented. Generally associated with variable amounts of organic material, phreatophytic or wetland fauna, and (or) secondary precipitates of carbonate or silica commonly derived from ground-water. Commonly consists of fossil deposits (latest Pleistocene or older in age) that formed in paludal to lacustrine environments associated with formerly expanded sites of groundwater paleodischarge that are entirely or largely inactive under current climatic conditions, although unit locally is associated with areas of active seepage or spring discharge. May include older finegrained (inactive) playa or lacustrine deposits locally. Thickness of unit variable, depending on age range of exposed units. Commonly from 0 to 10 $\mathrm{m}$ for exposed deposits, but possibly as much as 100 $\mathrm{m}$ or more in subsurface or in some dissected basin interiors (for example, southwestern Pahrump Valley; Page and others, in press)

QTIs Landslide block (Holocene to late Tertiary) — Generally brecciated but coherent (commonly recemented) bedrock outcrop, typically emplaced above or interstratified within surficial materials or upper basin-fill sediments in basin piedmonts or along range fronts. Thickness variable and poorly determined, as base of slide blocks generally are not exposed and thus basal depths must be estimated mainly from geophysical data. Exposed thicknesses commonly from 10 to $100 \mathrm{~m}$, but may range to more than $500 \mathrm{~m}$ in subsurface

QTsf Old alluvial, paludal, or lacustrine sediments (Pleistocene to late Tertiary) - Typically fine-grained fluvial, paludal, or lacustrine basin-fill sediments consisting of mixtures of poorly to well stratified silt, clay and fine sand. Variable induration, from unconsolidated to well consolidated. May contain local gravel-dominated channels and interbeds, paleodischarge deposits, interbedded tuffs, and (or) buried soils. Deposits are typically exposed in bluffs, ridges, or badland areas in dissected basin interiors (for example, beds of Lake Tecopa Allogroup of Morrison, 1999) or in uplifted fault blocks 
Table 2. Summary of selected surficial deposit units mapped in Death Valley ground-water model area.

[Table summarizes characteristics of the most common and distinctive surficial-deposit units in the Death Valley groundwater model mapping program subdivided into primarily alluvial units and other types of deposits. Mixed undifferentiated units (Qau and QTau) are not included because they consist of various proportions of other units listed below and thus lack a consistent set of characteristics. QTls, the bedrock landslide unit, is not included, because it resembles bedrock on the images and aerial photography and in the field consists of brecciated bedrock outcrop. Qayfe is not listed separately, as it is a variant of Qayf distinguished only by a thin crust of carbonate or salt on the surface of the deposit (see unit descriptions). The first three columns list map unit, general character, and age range estimated from correlations with specific local- to regional-scale studies with independent age control in and adjacent to the map area (listed in Menges and others, 2001). The next two columns list characteristics of units observed in the satellite image maps and black and white aerial photography used to interpret and compile units for map. The remainder of the columns list characteristics of deposits and related geomorphic surfaces that are primarily based on observations from field traverses. Characteristics are summarized from full area of Death Valley ground-water model, and thus vary significantly, reflecting the wide range of geologic, tectonic, and local climatic conditions across the region. N/A indicates not applicable.]

\begin{tabular}{|c|c|c|c|c|c|c|c|c|c|c|c|c|}
\hline \multirow[t]{2}{*}{ Unit $^{1}$} & \multirow[t]{2}{*}{ Type $^{2}$} & \multirow[t]{2}{*}{$\mathrm{Age}^{3}$} & \multicolumn{2}{|c|}{ Image/Photo Characteristics ${ }^{4}$} & \multirow{2}{*}{$\begin{array}{l}\text { Physiographic } \\
\text { Position }^{5}\end{array}$} & \multirow{2}{*}{$\begin{array}{c}\text { Internal } \\
\text { Dissection }\end{array}$} & \multicolumn{2}{|c|}{ Surface Characteristics ${ }^{7}$} & \multirow[t]{2}{*}{ Varnish $^{8}$} & \multirow{2}{*}{$\begin{array}{c}\text { General Soil } \\
\text { Characteristics }^{9}\end{array}$} & \multirow{2}{*}{$\begin{array}{c}\text { Typical } \\
\text { Grain Size }^{10}\end{array}$} & \multirow[t]{2}{*}{ Cementation $^{11}$} \\
\hline & & & Image Maps & $\begin{array}{c}\text { Black \& } \\
\text { White Aerial } \\
\text { Photography }\end{array}$ & & & Pavement & $\begin{array}{l}\text { Bar and } \\
\text { Swale }\end{array}$ & & & & \\
\hline Qc & $\begin{array}{l}\text { Channel } \\
\text { alluvium }\end{array}$ & Recent & $\begin{array}{l}\text { Variable, light } \\
\text { colored to white; } \\
\text { light blue where } \\
\text { salt encrusted }\end{array}$ & $\begin{array}{l}\text { White to } \\
\text { light gray }\end{array}$ & $\begin{array}{l}\text { Intrarange val- } \\
\text { leys, piedmonts, } \\
\text { and axial basin } \\
\text { drainages }\end{array}$ & $\begin{array}{l}\text { None to } \\
\text { minor } \\
\text { thalweg } \\
\text { incision }\end{array}$ & None & $\begin{array}{l}\text { Unmodified } \\
\text { primary }\end{array}$ & $\begin{array}{l}\text { None (only } \\
\text { inherited) }\end{array}$ & None & $\begin{array}{l}\text { Variable, } \\
\text { from mixed } \\
\text { gravel to } \\
\text { fine sand }\end{array}$ & $\begin{array}{l}\text { None (except } \\
\text { local gully } \\
\text { bed) }\end{array}$ \\
\hline Qay & $\begin{array}{l}\text { Medium - } \\
\text { to coarse- } \\
\text { grained } \\
\text { alluvium }\end{array}$ & $\begin{array}{l}\text { Recent to } \\
\text { Holocene, } \\
\text { locally latest } \\
\text { Pleistocene }\end{array}$ & $\begin{array}{l}\text { Light to dark } \\
\text { colors, } \\
\text { including } \\
\text { browns; rough to } \\
\text { medium textures }\end{array}$ & $\begin{array}{l}\text { Light to } \\
\text { medium gray }\end{array}$ & $\begin{array}{c}\text { Proximal to } \\
\text { distal } \\
\text { piedmonts, } \\
\text { terraces, coarse } \\
\text { axial drainages }\end{array}$ & $\begin{array}{l}\text { None to } \\
\text { minor } \\
\text { (mostly } \\
\text { primary) }\end{array}$ & $\begin{array}{l}\text { None to } \\
\text { weak, } \\
\text { locally } \\
\text { moderate }\end{array}$ & $\begin{array}{l}\text { Unmodified } \\
\text { to faint (but } \\
\text { discernable) }\end{array}$ & $\begin{array}{l}\text { None to } \\
\text { moderate }\end{array}$ & $\begin{array}{l}\text { None to weak } \\
\text { (cambic and Stage I } \\
\text { calcic horizons) }\end{array}$ & $\begin{array}{l}\text { Coarse to } \\
\text { fine gravel } \\
\text { and sand }\end{array}$ & None \\
\hline Qayo & $\begin{array}{l}\text { Medium - } \\
\text { to coarse- } \\
\text { grained } \\
\text { alluvium }\end{array}$ & $\begin{array}{l}\text { Middle to } \\
\text { early } \\
\text { Holocene, } \\
\text { locally latest } \\
\text { Pleistocene }\end{array}$ & $\begin{array}{l}\text { Medium to dark } \\
\text { colors, } \\
\text { including } \\
\text { browns; } \\
\text { medium textures }\end{array}$ & $\begin{array}{l}\text { Medium to } \\
\text { dark grays }\end{array}$ & $\begin{array}{l}\text { Proximal to } \\
\text { distal } \\
\text { piedmonts, } \\
\text { terraces }\end{array}$ & $\begin{array}{l}\text { None to } \\
\text { minor }\end{array}$ & $\begin{array}{l}\text { Weak to } \\
\text { locally } \\
\text { moderate }\end{array}$ & $\begin{array}{l}\text { Faint, but } \\
\text { discernable }\end{array}$ & $\begin{array}{l}\text { Weak to } \\
\text { moderate }\end{array}$ & $\begin{array}{l}\text { Weak (cambic and } \\
\text { Stage I calcic } \\
\text { horizons) }\end{array}$ & $\begin{array}{l}\text { Coarse to } \\
\text { fine gravel } \\
\text { and sand }\end{array}$ & None \\
\hline Qayf & $\begin{array}{l}\text { Fine- } \\
\text { grained } \\
\text { alluvium }\end{array}$ & $\begin{array}{l}\text { Recent to } \\
\text { Holocene, } \\
\text { locally latest } \\
\text { Pleistocene }\end{array}$ & $\begin{array}{l}\text { Light to medium } \\
\text { colors, } \\
\text { including brown; } \\
\text { light blue where } \\
\text { salt encrusted; } \\
\text { smooth to } \\
\text { medium textures }\end{array}$ & $\begin{array}{l}\text { White and } \\
\text { light to } \\
\text { medium } \\
\text { grays }\end{array}$ & $\begin{array}{l}\text { Mostly fine- } \\
\text { grained axial } \\
\text { drainages and } \\
\text { interior alluvial } \\
\text { plains, some } \\
\text { distal piedmonts }\end{array}$ & $\begin{array}{l}\text { None to very } \\
\text { minor }\end{array}$ & $\begin{array}{l}\text { None to } \\
\text { weak, } \\
\text { locally } \\
\text { moderate }\end{array}$ & $\begin{array}{l}\text { None to } \\
\text { faint }\end{array}$ & $\begin{array}{l}\text { None to } \\
\text { moderate }\end{array}$ & $\begin{array}{c}\text { None to weak } \\
\text { (cambic and Stage I } \\
\text { carbonate horizons) }\end{array}$ & $\begin{array}{l}\text { Sand, silt, } \\
\text { minor fine } \\
\text { gravel }\end{array}$ & None \\
\hline Qao & $\begin{array}{l}\text { Medium- } \\
\text { to coarse- } \\
\text { grained } \\
\text { alluvium }\end{array}$ & Pleistocene & $\begin{array}{l}\text { Light to dark } \\
\text { colors, includ- } \\
\text { ing brown to } \\
\text { reddish brown; } \\
\text { smooth to } \\
\text { medium tex- } \\
\text { tures }\end{array}$ & $\begin{array}{l}\text { Light to } \\
\text { medium } \\
\text { grays }\end{array}$ & $\begin{array}{l}\text { Proximal to } \\
\text { medial, and } \\
\text { locally distal, } \\
\text { piedmonts; } \\
\text { terraces in } \\
\text { intrarange } \\
\text { valleys }\end{array}$ & $\begin{array}{l}\text { Commonly } \\
\text { moderate to } \\
\text { strong; } \\
\text { locally minor }\end{array}$ & $\begin{array}{c}\text { Strong to } \\
\text { moderate; } \\
\text { present on } \\
\text { interfluves } \\
\text { where } \\
\text { dissected }\end{array}$ & None & $\begin{array}{l}\text { Strong to } \\
\text { moderate }\end{array}$ & $\begin{array}{l}\text { Strong to moderate; } \\
\text { includes argillic and } \\
\text { (or) Stage II-IV } \\
\text { calcic to petrocalcic } \\
\text { horizons }\end{array}$ & $\begin{array}{l}\text { Coarse to } \\
\text { fine gravel } \\
\text { and sand }\end{array}$ & $\begin{array}{l}\text { Poor to } \\
\text { moderate }\end{array}$ \\
\hline QTa & $\begin{array}{l}\text { Medium - } \\
\text { to coarse- } \\
\text { grained } \\
\text { alluvium }\end{array}$ & $\begin{array}{c}\text { Middle } \\
\text { Pleistocene to } \\
\text { Pliocene }\end{array}$ & $\begin{array}{l}\text { Light to medium } \\
\text { colors, possible } \\
\text { light-brown tint; } \\
\text { smooth to } \\
\text { medium textures }\end{array}$ & $\begin{array}{l}\text { Light to } \\
\text { medium } \\
\text { grays }\end{array}$ & $\begin{array}{l}\text { Proximal to } \\
\text { locally medial } \\
\text { piedmonts; } \\
\text { range-front } \\
\text { embayments; } \\
\text { intrarange } \\
\text { valleys }\end{array}$ & $\begin{array}{l}\text { Commonly } \\
\text { strong and } \\
\text { deep (bal- } \\
\text { lena topogra- } \\
\text { phy) }\end{array}$ & $\begin{array}{l}\text { None to } \\
\text { weak, } \\
\text { commonly } \\
\text { with } \\
\text { carbonate } \\
\text { chips }\end{array}$ & None & $\begin{array}{l}\text { None to } \\
\text { weakly } \\
\text { preserved }\end{array}$ & $\begin{array}{l}\text { Strong to moderate; } \\
\text { variably eroded } \\
\text { Stage III-V } \\
\text { petrocalcic where } \\
\text { preserved }\end{array}$ & $\begin{array}{l}\text { Coarse to } \\
\text { fine gravel } \\
\text { and sand }\end{array}$ & $\begin{array}{l}\text { Moderate to } \\
\text { strong }\end{array}$ \\
\hline
\end{tabular}


Table 2-Continued. Summary of selected surficial deposit units mapped in Death Valley ground-water model area.

[Table summarizes characteristics of the most common and distinctive surficial-deposit units in the Death Valley groundwater model mapping program subdivided into primarily alluvial units and other types of deposits. Mixed undifferentiated units (Qau and QTau) are not included because they consist of various proportions of other units listed below and thus lack a consistent set of characteristics. QTls, the bedrock landslide unit, is not included, because it resembles bedrock on the images and aerial photography and in the field consists of brecciated bedrock outcrop. Qayfe is not listed separately, as it is a variant of Qayf distinguished only by a thin crust of carbonate or salt on the surface of the deposit (see unit descriptions). The first three columns list map unit, general character, and age range estimated from correlations with specific local- to regional-scale studies with independent age control in and adjacent to the map area (listed in Menges and others, 2001). The next two columns list characteristics of units observed in the satellite image maps and black and white aerial photography used to interpret and compile units for map. The remainder of the columns list characteristics of deposits and related geomorphic surfaces that are primarily based on observations from field traverses. Characteristics are summarized from full area of Death Valley ground-water model, and thus vary significantly, reflecting the wide range of geologic, tectonic, and local climatic conditions across the region. N/A indicates not applicable.]

\begin{tabular}{|c|c|c|c|c|c|c|c|c|c|c|c|c|}
\hline Qlc & $\begin{array}{c}\text { Medium to } \\
\text { coarse- } \\
\text { grained } \\
\text { lacustrine } \\
\text { deposits }\end{array}$ & $\begin{array}{l}\text { Late to } \\
\text { middle } \\
\text { Pleistocene }\end{array}$ & $\begin{array}{l}\text { Light to dark } \\
\text { colors, } \\
\text { including brown } \\
\text { to reddish } \\
\text { brown; smooth } \\
\text { to medium } \\
\text { textures }\end{array}$ & $\begin{array}{l}\text { Light to } \\
\text { medium } \\
\text { grays }\end{array}$ & $\begin{array}{l}\text { Mostly medial to } \\
\text { distal piedmonts }\end{array}$ & $\begin{array}{l}\text { Commonly } \\
\text { moderate to } \\
\text { strong; } \\
\text { locally minor }\end{array}$ & $\begin{array}{c}\text { Strong to } \\
\text { moderate, } \\
\text { but present } \\
\text { on } \\
\text { interfluves } \\
\text { where } \\
\text { dissected }\end{array}$ & None & $\begin{array}{l}\text { Strong to } \\
\text { moderate }\end{array}$ & $\begin{array}{l}\text { Strong to moderate; } \\
\text { includes argillic and } \\
\text { (or) Stage II-IV } \\
\text { calcic to petrocalcic } \\
\text { horizons }\end{array}$ & $\begin{array}{l}\text { Medium- } \\
\text { to fine } \\
\text { gravel and } \\
\text { sand } \\
\text { (moderately } \\
\text { to well } \\
\text { sorted) }\end{array}$ & $\begin{array}{l}\text { Poor to } \\
\text { moderate }\end{array}$ \\
\hline QTsf & $\begin{array}{c}\text { Fine- } \\
\text { grained } \\
\text { lacustrine, } \\
\text { inactive } \\
\text { playa, and } \\
\text { alluvial } \\
\text { deposits }\end{array}$ & $\begin{array}{l}\text { Pleistocene to } \\
\text { Pliocene }\end{array}$ & $\begin{array}{l}\text { White to light } \\
\text { colors; medium } \\
\text { to smooth } \\
\text { textures }\end{array}$ & $\begin{array}{l}\text { White to } \\
\text { light grays }\end{array}$ & $\begin{array}{l}\text { Variable, } \\
\text { including } \\
\text { proximal to dis- } \\
\text { tal fans and } \\
\text { basin interiors }\end{array}$ & $\begin{array}{l}\text { Moderate to } \\
\text { strong, in } \\
\text { dissected } \\
\text { basins; } \\
\text { locally none }\end{array}$ & N/A & N/A & N/A & $\begin{array}{l}\text { Local buried paleo- } \\
\text { sols, variable weak to } \\
\text { strong development }\end{array}$ & $\begin{array}{c}\text { Silt, clay, } \\
\text { fine sand; } \\
\text { local gravel } \\
\text { interbeds }\end{array}$ & $\begin{array}{l}\text { Poor to } \\
\text { moderate }\end{array}$ \\
\hline Qp & $\begin{array}{c}\text { Active } \\
\text { playa and } \\
\text { salt flat } \\
\text { deposits }\end{array}$ & $\begin{array}{l}\text { Recent to late } \\
\text { Holocene }\end{array}$ & $\begin{array}{l}\text { White to } \\
\text { variegated light } \\
\text { and pastel col- } \\
\text { ors; light blue } \\
\text { where moist; } \\
\text { smooth textures }\end{array}$ & $\begin{array}{l}\text { White to } \\
\text { light grays }\end{array}$ & Basin interiors & None & None & None & None & $\begin{array}{c}\text { None; local } \\
\text { near-surface } \\
\text { encrustations on salt } \\
\text { pans }\end{array}$ & $\begin{array}{l}\text { Clay and } \\
\text { silt; local } \\
\text { fine sand }\end{array}$ & $\begin{array}{l}\text { None to } \\
\text { moderate (on } \\
\text { salt pans) }\end{array}$ \\
\hline QTd & $\begin{array}{c}\text { Inactive } \\
\text { and active } \\
\text { discharge } \\
\text { deposits }\end{array}$ & $\begin{array}{l}\text { Recent to } \\
\text { Pliocene }\end{array}$ & $\begin{array}{l}\text { White to } \\
\text { variegated light } \\
\text { and pastel } \\
\text { colors; light blue } \\
\text { where moist; } \\
\text { smooth to } \\
\text { medium } \\
\text { textures; local } \\
\text { green vegetation }\end{array}$ & $\begin{array}{l}\text { White to } \\
\text { light grays }\end{array}$ & $\begin{array}{c}\text { Mostly distal } \\
\text { piedmonts and } \\
\text { basin interiors; } \\
\text { locally proximal } \\
\text { to medial } \\
\text { piedmonts }\end{array}$ & $\begin{array}{l}\text { None to } \\
\text { moderate }\end{array}$ & $\begin{array}{l}\text { None; } \\
\text { locally } \\
\text { weak to } \\
\text { moderate on } \\
\text { alluvial } \\
\text { caps }\end{array}$ & $\begin{array}{l}\text { N/A; none } \\
\text { to weak (on } \\
\text { alluvial } \\
\text { caps) }\end{array}$ & $\begin{array}{l}\text { None to } \\
\text { weak (on } \\
\text { alluvial } \\
\text { caps) }\end{array}$ & $\begin{array}{l}\text { None to moderate } \\
\text { (may include St I-II } \\
\text { calcic horizons) }\end{array}$ & $\begin{array}{l}\text { Clay, silt, } \\
\text { fine sand; } \\
\text { local fine } \\
\text { gravels and } \\
\text { organic } \\
\text { mats }\end{array}$ & $\begin{array}{c}\text { None to } \\
\text { moderate; } \\
\text { locally strong } \\
\text { where } \\
\text { crystalline } \\
\text { precipitate }\end{array}$ \\
\hline Qe & $\begin{array}{l}\text { Eolian } \\
\text { deposits }\end{array}$ & $\begin{array}{l}\text { Holocene to } \\
\text { middle } \\
\text { Pleistocene }\end{array}$ & $\begin{array}{l}\text { Light brown, } \\
\text { pinkish gray to } \\
\text { pink; medium } \\
\text { textures }\end{array}$ & Light grays & $\begin{array}{c}\text { Mostly basin } \\
\text { interiors; locally } \\
\text { variable } \\
\text { piedmont }\end{array}$ & None & None & N/A & None & None & $\begin{array}{l}\text { Fine to } \\
\text { medium } \\
\text { sand; silt }\end{array}$ & None \\
\hline
\end{tabular}

Labels used to identify surficial units for Death Valley ground-water model area geologic map. Units are subdivided into alluvial and ond
posite or mixed age-range alluvial units (Qau and QTau) and the bedrock landslide unit (QT1s) for reasons explained in table header.

${ }^{2}$ General type or classification of deposit, including general size range of coarse fraction, such that medium- to coarse-grained refers to gravel and sand and fine-grained refers to sand, silt and clay.

${ }^{3}$ Age range of deposits, based on correlations to local or regional studies with geochronologic control listed in Menges and others (2001).

${ }^{4}$ Typical characteristics of unit observed in satellite image maps and aerial photography used to interpret and compile maps. Satellite image refers to the specially processed Landsat 5 Thematic Mapper image projected onto $1: 100,000-$

${ }^{5}$ Typical physiographic positions of unit within landscape, commonly given in reference to alluvial basins and (or) bedrock ranges.

${ }^{6}$ Relative amount of local dissection or incision of drainages within or along margins of given mapped area of deposit. Common depth ranges include $0-2 \mathrm{~m}$ (minor), $2-5 \mathrm{~m}$ (moderate), and $>5 \mathrm{~m}$ (strong).

${ }^{7}$ Degree of desert varnish observed at surface, given qualitatively in reference to darkening of tops and (or) reddening of undersides of surface clasts.

${ }^{8}$ Degree of desert varnish observed at surface, given qualitatively in reference to darkening of tops and (or) reddening of undersides of surface clasts.

${ }^{9}$ General strength of maximum soil development associated with upper surface of deposits, typically as observed in natural outcrops (gullies) or road cuts, or as exposed in shallow pits. Soil pits exposing the full depth range of deep profiles could not be excavated during the reconnaissance field traverses required for this project. Observations focused on relative degree of development of horizons of secondary accumulation of carbonate, after Machette (1985), an carbonate chips, carbonate rinds on clasts, and materials brought up from burrowing insects or rodents.

${ }^{10}$ Typical textural size range of deposits, given for gravels in terms of coarse (cobble to boulder) or fine (pebble to cobble) grained.

${ }^{11}$ Degree of internal cementation or induration throughout deposits, below surface zone of soil development. Bonding agent varies from fines (silt, clay) in uncemented to poorly cemented deposits to secondary carbonate, salt, or silica
cement in moderately to strongly cemented materials. 
(beds of Confidence Hills Formation of Beratan and others, 1999), although unit locally includes finegrained primarily lacustrine deposits as young as late to middle Pleistocene related to pluvial lakes within enclosed basins (for example, northern Death Valley; Klinger and Sarna-Wojcicki, 2001). Variable thickness from 0 to greater than $100 \mathrm{~m}$ in exposed sections. Total thickness in basin subsurface may exceed $300 \mathrm{~m}$

Qao Old alluvium (late to middle Pleistocene)-Typically medium- to coarse-grained gravel (boulder to pebble gravel dominated) and sand deposits in proximal and medial basin positions, but may locally include regions with fine-grained sand and silt at surface in some closed-basin settings. Variable induration but generally moderately consolidated to unconsolidated below potentially cemented well-developed soils. Has moderately to well-developed soils, moderate to strong varnish development on clasts, and moderate- to well-developed surface pavements with no detectable bar-and-swale landforms. Variable local relief, ranging from undissected to well incised, depending on local base-level conditions, but typically with at least some local incision; unit typically contains at least some varnished pavement surfaces preserved on flat to broadly rounded interfluves even where strongly dissected. Thickness of individually mapped units at surface typically from 0 to $30 \mathrm{~m}$, but may increase to $50-100 \mathrm{~m}$ along tectonically active range-fronts. Aggregate thickness of all Pleistocene-age alluvial units adjacent to tectonically active range fronts may exceed $500 \mathrm{~m}$ in subsurface

Qlc Old lacustrine deposits (late to middle Pleistocene) Generally fine- to meidum-grained gravel (mostly pebble to cobble, some small boulder) and sand, related primarily to pluvial lakes formed in closed basins such as central Death Valley (Machette, Klinger, and Knott, 2001). May locally include finegrained sand and silt beds and (or) variably cemented tufa deposits. Generally moderately consolidated to unconsolidated beneath surface soils, except where associated with cemented densely crystalline tufa. Has moderate- to well-developed soils, moderate to strong varnish development on surface clasts, and moderate- to well-developed surface pavements with no detectable bar and swale landforms. Variable local relief, ranging from undissected to deeply dissected, depending on local baselevel conditions, but typically with at least some local incision; unit typically contains at least some varnished pavement surfaces preserved on flat to broadly rounded interfluves even where strongly dissected. Unit similar in many respects to unit Qao, but is differentiable based on generally finer gravel texture, better sorting and rounding of coarse fraction, and common association with lacustrine depositional features and landforms (for example, shorelines; spits and bars; forset, backset, or deltaic stratification). Thickness variable, but typically from 0 to $20 \mathrm{~m}$; locally as much as $50 \mathrm{~m}$

QTa

Oldest alluvium (middle Pleistocene to late Ter

tiary)_Generally medium- to coarse-grained gravel (boulder to pebble) and sand. Variable induration, from poorly consolidated beneath cemented surface soils to well cemented throughout. Mostly associated with old dissected fans and (or) gravelsand dominated basin fill deposits, commonly located at basin margins. Typically has strongly developed or eroded relict soils (usually dominated by variably degraded cemented petrocalcic to petrosalic horizons). Generally strongly incised into ballena (ridge-ravine) topography with little or no preservation of pavements or original surfaces on narrow interfluves. Thickness generally from 0 to $100 \mathrm{~m}$, but may increase to $300 \mathrm{~m}$ locally. Generally not preserved at surface on basin side of tectonically active range-front faults

\section{Bedrock Units}

Within the Tertiary section, we have followed the mapping strategy of Ekren and others (1977). Sedimentary and volcanic units are subdivided based upon age range. Within each age range, the rocks are further subdivided into lava flows, tuffs, and associated sedimentary rocks. These units represent four major stages in the Tertiary tectonic evolution of the region. Unit 1 consists of sedimentary rocks that predate the oldest Tertiary volcanic units associated with extension. These rocks fall into regionally extensive formations which have been significantly deformed by more recent extension and which everywhere lack volcanic material. Unit 2 consists of the oldest Tertiary volcanic sequence ranging in age from 27 to $32 \mathrm{Ma}$. These rocks are commonly difficult to differentiate in the field and in thin section and consequently source associations are poorly constrained. No sedimentary rocks associated with unit 2 are exposed within the map area. Unit 3 consists of the younger sequence of calc-alkaline volcanic rocks and associated sedimentary units ranging in age from 18 to $27 \mathrm{Ma}$. Unit 4 consists of the entire bimodal sequence of volcanic rocks and associated sedimentary rocks ranging in age from 5 to $17 \mathrm{Ma}$. Within the Nevada Test Site and Death Valley regions, these units are subdivided into a more detailed stratigraphic sequence representing both the Death Valley volcanic field and southwestern Nevada volcanic field. Sedimentary rocks of unit 4 are not subdivided due to a lack of consistent, regional stratigraphic correlations. Felsic-composition lava flows and intrusive rocks are not subdivided due to lack of age data.

\section{Silicic to Intermediate-composition Volcanic Rocks}

Qa Young intermediate-composition lava flows, undi vided (Pleistocene) - Partially reworked, intermediate-composition lava flows, pyroclastic rocks and 
interbedded sedimentary rocks exposed in the eastern-most Saline Range and the northern tip of the Cottonwood Mountains (Strand, 1967; Burchfiel, 1969; Streitz and Stinson, 1974)

Volcanic rocks, undivided (Pliocene to Oligocene)Volcanic rocks whose age and stratigraphic position are poorly constrained

$\operatorname{Tr}$

Felsic-composition lava flows, undivided (Pliocene to Oligocene)_-Mostly resistant, mostly gray, white, and tan, rhyolitic lava flows and volcanic domes, and subordinate ash-flow and air-fall tuff. Includes many rhyolite and lesser trachyte and comendite masses, many of them associated with calderas. Includes the Oddie Rhyolite of Esmeralda County (Albers and Stewart, 1972)

Ta4 Intermediate-composition lava flows, unit 4 (Pliocene and Miocene)-Mostly resistant, intermediatecomposition lava flows, flow breccia, and subordinate volcanic mudflow breccia. Includes the andesite of Sarcobatus Flat west of the Nevada Test Site (Slate and others, 2000), 9-12 Ma dacitic rocks in Death Valley and the Grapevine Mountains (Wright and others, in press), and 5.9-Ma porphyritic latite or trachyandesite and rhyolitic to andesitic volcanic breccia in Esmeralda County (Albers and Stewart, 1972). Age range: 5-17 Ma

Tt4 Ash-flow tuffs and interbedded air-fall tuffs, unit 4 (Pliocene and Miocene)-Mostly resistant, poorly to highly welded, mostly silicic ash-flow tuffs and minor air-fall tuff. Includes the peralkaline Kane Wash Tuff (14.4-14.7 Ma) and older (15-16 Ma) peralkaline tuffs formerly included in the Kane Wash Tuff (Scott and others, 1995a). Where not mapped separately, includes tuffs of the Timber Mountain Group. Includes the upper nonwelded ash-flow tuff (6 Ma) and the upper welded ash-flow tuff (5.9-6.1 Ma) of Albers and Stewart (1972) in Esmeralda County. Age range: 5-17 Ma

Rocks of the southern Death Valley region (Miocene)_Lava flows and tuffs exposed in southern Death Valley and areas to the south and east including the Black Mountains, Greenwater Valley, Greenwater Range, southern Amargosa Desert, southern Panamint Range, Owlshead Mountains, Sperry Hills, and northern Kingston Range. These rocks are described in detail by Wright and others (in press). All dates taken directly from Wright and others (in press). Divided into:

Tvg Greenwater Volcanics-Rhyodacite flows and airfall tuffs exposed in the northern Greenwater Range and Black Mountains. Age Range: 5.4$6.0 \mathrm{Ma}$

Tar Intermediate- to felsic-composition lava flows of the central Death Valley volcanic field-Andesitic to rhyolitic lava flows and interbedded tuffs in the Black Mountains, Greenwater Range, and Panamint Mountains where unit includes Rhodes Tuff,

Sheephead Andesite, and Shoshone Volcanics (811.5 Ma). Includes intermediate- to felsic-composition hypabyssal intrusive rocks in Black Mountains and Greenwater Range. Also includes dacitic lava flows in the southern Black Mountains and southern Resting Spring Range. Age range: 8-12 Ma

Tas

Tst

Tmt

Tpt

Tw

Tct

Tbt

Tlt

Tqv 
Older ash-flow tuffs and lava sequences, undi vided-Peralkaline and rhyolite ash-flow tuff, lava flows, and associated rocks of about 14.9-16 Ma. Consists of the comendite of Ocher Ridge, Tub Spring Tuff, comendite of Emigrant Valley, older tunnel beds, tuff of Yucca Flat, Redrock Valley Tuff, tuff of Twin Peaks, and volcanic rocks of Gold Flat. Comendite units are from local sources but the sources of the tuffs are unknown, although some could be from the Nevada Test Site

Tkv Lava flows of the Belted Range-Rhyolite and latite lava flow sequences. Consists of the rhyolite of Belted Peak, rhyolite of Wheelbarrow Peak, and latite of Kawich Valley

Ta3 Intermediate-composition lava flows, unit 3 (Miocene and Oligocene)-Mostly resistant, intermediatecomposition lava flows, flow breccia, and subordinate volcanic mudflow breccia. Includes the Mizpah Trachyte (20.4 Ma), the Milltown Andesite (21.5 Ma), and 20.8-21.6 Ma dacitic rocks and the Chispa Andesite in the northern part of the area (Albers and Stewart, 1972; Cornwall, 1972; Kleinhampl and Ziony, 1985). Age range: $19-26 \mathrm{Ma}$

Tt3 Ash-flow tuffs and interbedded air-fall tuffs, unit 3 (Miocene and Oligocene) - Mostly resistant, poorly to highly welded, mostly silicic ash-flow tuffs and minor air-fall tuff. Includes the Hiko Tuff (18.218.6 Ma; Rowley and others, 1995), Fraction Tuff (18.7-20.5 Ma; Best and others, 1989b), tuff of Saulsbury Wash (21.6 Ma; Kleinhampl and Ziony, 1985), Harmony Hills Tuff (22.0-22.5 Ma; Rowley and others, 1995), Pahranagat Formation (22.39 Ma; Best and others, 1995), Condor Canyon Formation (22.8-23.7 Ma; Rowley and others, 1995), Leach Canyon Formation (23.8 Ma; Best and others, 1989b; Rowley and others, 1994), Bates Mountain Tuff (23-24 Ma; Best and others, 1989b), tuff of White Blotch Spring (24-25 Ma; Ekren and others, 1977), tuffs of Antelope Springs (Cornwall, 1972), rocks of the Reveille Range (24-25 Ma; Kleinhampl and Ziony, 1985), tuff of Kiln Canyon (24-25 Ma (Kleinhampl and Ziony, 1985), tuff of the Quinn Canyon Range, Kendall Tuff (Albers and Stewart, 1972), Vindicator Rhyolite (Albers and Stewart, 1972), tuff of Murphy Gap, tuff of Bald Mountain (about $25 \mathrm{Ma}$; Best and others, 1989b), Shingle Pass Tuff (26.0-26.7 Ma; Best and others, 1989b), tuff of Hancock Summit (about $26 \mathrm{Ma}$; Best and others, 1989b), and Isom Formation (25.7-27.0 Ma; Best and others, 1989b; Rowley and others, 1994). Also includes poorly dated (but less than $25 \mathrm{Ma}$ ) young tuffs of the Pancake caldera complex, and poorly dated tuffs of the Hannapah and Ellendale mining districts, including the tuff of McKinney Tanks and the tuff of Hannapah (Kleinhampl and Ziony, 1985). Age range: $18-27 \mathrm{Ma}$ (Oligocene)-Mostly resistant, intermediate-

composition lava flows, flow breccia, and subordinate volcanic mudflow breccia. Age range: 27-32 Ma

Tt2

\section{Basaltic Volcanic Rocks}

Ob Young basaltic lava flows (Holocene to Pleistocene) Mostly resistant, basaltic lava flows, flow breccia, scoria, and cinder cones

QTb Basaltic lava flows, undivided (Pleistocene to Miocene)-Mapped where age is less certain. Includes Malpais Basalt and Rabbit Spring Formation, undivided, of Esmeralda County (Albers and Stewart, 1972) and Pliocene? basaltic rocks in the Reveille Range (Cornwall, 1972; Kleinhampl and Ziony, 1985)

Tb Old basaltic lava flows (Pliocene to Miocene) Mostly resistant, basaltic lava flows, flow breccia, scoria, and cinder cones. Includes the Mira Basalt (Albers and Stewart, 1972)

\section{Intrusive Rocks}

Tgy Young granitic intrusive rocks (Miocene)—Mostly resistant silicic intrusions. Includes intrusive rocks on Timber Mountain associated with the tuffs of the Timber Mountain Group (11.4-11.6 Ma; Slate and others, 2000) and rocks in the Death Valley region (8.5-12.5 Ma; Wright and others, in press)

Tai Younger intermediate-composition intrusive rocks (Miocene to Oligocene)-Mostly resistant plugs and dikes in the Panamint Range and Owlshead Mountains, which are correlative with a $12.5 \mathrm{Ma}$ sill in the Kingston Range (Wright and others, in press). In the central and northern sections of the map area, this unit includes exposures associated with caldera magmatism and shallow plutonism ranging in age from 11-32 Ma (Ekren and others, 1971; Cornwall, 1972; Ekren and others, 1977; Kleinhampl and Ziony, 1985; Slate and others, 2000). Locally includes associated extrusive rocks 
Tws Gabbro to diorite intrusive rocks of Willow Springs (Miocene)-Mostly resistant and mafic intrusion of about 11.6 Ma in the Black Mountains associated with the Willow Springs pluton (Wright and others, in press)

Tgo Older granitic intrusive rocks (Miocene? to Oli gocene)—Mostly resistant silicic intrusions. Includes intrusive quartz monzonitic rocks in the northern Quinn Canyon Range (26.8 Ma; Kleinhampl and Ziony, 1985) and coarse-grained rhyolite porphyry in the Cactus Range which intrudes the tuff of White Blotch Spring (Cornwall, 1972)

TKi Older intermediate-composition intrusive rocks (Oli gocene to Cretaceous)—Mostly resistant intrusions and dikes whose age is poorly constrained. Includes "dacite to gabbro dikes, many too small to show at map scale, along the west side of Bare Mountain (Slate and others, 2000)"

TKd Mafic intrusive rocks (Oligocene to Cretaceous) Mostly resistant mafic intrusions and dikes. Exposed in the Palmetto and Montezuma ranges of Esmeralda County (Albers and Stewart, 1972)

Tkg Oldest granitic intrusive rocks (Tertiary? to Trias sic)—Mostly resistant, mostly silicic intrusions and dikes. Ages generally decrease eastward across the map area from predominantly Jurassic in the western ranges to predominantly Cretaceous in the eastern ranges. Includes exposures along the eastern Cottonwood Mountains of known Triassic age (McAllister, 1956)

J K qm Avawatz Mountains quartz monzodiorite, undivided (Early Jurassic to Late Triassic)—Coarse-grained quartz monzodioritic plutonic rocks underlying most of the Avawatz Range, and exposed as fault slices near the Garlock fault and in the Slate Range and southern Panamint Range. $\mathrm{K} / \mathrm{Ar}$ and $\mathrm{Rb} / \mathrm{Sr}$ ages fall within the range of 180 to $220 \mathrm{Ma}$ (Wright and others, in press)

\section{Sedimentary and Metamorphic Rocks}

Ts Sedimentary rocks, undivided (Pliocene to Eocene)-Poorly to well consolidated fluvial and lacustrine sedimentary rocks whose age is poorly constrained. Includes the Siebert Tuff in the Tonopah area (Albers and Stewart, 1972). Locally divided into:

Ts4 Sedimentary rocks, unit 4 (Pliocene and Miocene)-Poorly to moderately consolidated, mostly fluvial sandstone, conglomerate, mudstone, limestone, and siltstone. The upper part of the unit is composed of deposits in local basins that reflect the present topography formed during basin-range extension. These deposits include unnamed basinfill sediments, the Funeral Formation, the Furnace Creek Formation, caldera moat-filling sediments, bedded tuff and sedimentary rocks, and sedimentary rocks and landslide deposits exposed in and near the Nevada Test Site (Slate and others, 2000; Wright and others, in press). Includes the sedimentary deposits (7-14 Ma) of the Shadow Valley basin (Wright and others, in press). In Esmeralda County, the upper part of the unit includes the Pozo Formation, deposits that overlie tuff dated at $5.9 \mathrm{Ma}$, and other (4-17 Ma) deposits (Albers and Stewart, 1972). The lower part of the unit includes prebasin-range deposits filling local basins that predate the present topography. On and near the Nevada Test Site, these rocks, previously called the rocks of Pavits Spring, are of about 11.7-18.3(?) Ma (Slate and others, 2000). In Esmeralda County, the lower part of the unit contains the Esmeralda Formation. Age range: 5-17 Ma

Tls

Landslide and mega-breccia deposits (Miocene to Oligocene)—Large, angular blocks of older bedrock ranging in size up to hundreds of meters, commonly retaining original sedimentary bedding, contained within a recemented matrix of identical lithology. Generally underlain by mappable, gravity-induced faults related to Tertiary extension (Slate and others, 2000). Includes masses in the Timpahute Range inferred to post-date $24 \mathrm{Ma}$ (Ekren and others, 1977), in the Sheep Range where deposition was synchronous with deposition of the Horse Springs Formation (Guth, 1981; P. Guth and J. Yount, unpublished mapping, 1994), in the Reveille Range dated at 18.5-26 Ma (Ekren and other, 1973), in the Beatty region dated at 10-12.7 Ma (Slate and others, 2000), in the Nevada Test Site region overlying volcanic rocks dated at 13.7 to $15.3 \mathrm{Ma}$ and overlain by $11.6 \mathrm{Ma}$ volcanic rocks (Slate and others, 2000), at the northern end of the Spring Mountains dated at 12.7-13.7 Ma (Slate and others, 2000), and in the Blue Diamond area where the age is unknown (Page and others, in press). Unit is everywhere assumed to be older than $10 \mathrm{Ma}$

Tso Sedimentary rocks older than the rocks of the Nevada Test Site and vicinity (Miocene to Eocene?)—Moderately consolidated, fluvial and lacustrine sandstone, conglomerate, limestone, mudstone, and siltstone whose age is poorly constrained. Includes conglomerate with interbedded lacustrine limestone, siltstone, sandstone and a 30.2 Ma air-fall tuff (Barnes and others, 1982), formerly called the rocks of Winapi Wash on the northern side of the Spotted Range. Includes the upper tuffaceous sandstone and lower conglomerate of the Titus Canyon Formation along the north side of the Funeral and Grapevine Mountains (Slate and others, 2000). Also includes a small exposure north of Yucca Flat composed of locally derived clasts of the Eleana Formation which separates the Paleozoic basement rock from overlying Tertiary volcanic units beneath 
much of the northern end of Yucca Flat as interpreted from drill-hole data (J. Cole, oral communication, 2001)

Ts3

Sedimentary rocks, unit 3 (Miocene and Oli gocene)-Moderately to well consolidated, fluvial and lacustrine sandstone, limestone, conglomerate, and mudstone. Deposited in basins that formed before the present topography was developed. Includes the Sandstorm Formation of Esmeralda County (Albers and Stewart, 1972), the Horse Spring Formation in the southern Las Vegas Range (Page and others, in press), and deposits younger than the Titus Canyon Formation in Death Valley National Park (Wright and others, in press). Age range: $18-26 \mathrm{Ma}$

Ts1 Sedimentary rocks, unit 1 (Eocene and Pale ocene)-Coarse, predominantly conglomeratic sedimentary rocks which pre-date Tertiary volcanic activity based on a lack of volcanic clasts and stratigraphic relationships. Includes the Sheep Pass Formation in Lincoln County (Tschanz and Pampeyan, 1970; Ekren and others, 1977) and the fanglomerate of Ekren and others (1971) in the Mount Helen area

Mzsv Sedimentary and volcanic rocks, undivided (Meso zoic)_Exposed throughout the southwestern part of the map area including the southern Inyo Mountains, Slate Range, southern Panamint Range, and Avawatz Mountains. This unit is locally metamorphosed and includes interbedded sedimentary and volcanic rocks (Wright and others, in press). Includes the Butte Valley Formation in the southern Panamint Mountains which is age-equivalent to the Moenkopi Formation in the eastern part of the map area (Johnson, 1957)

KIw Lavinia Wash sequence (Upper and Lower Creta ceous)_Heterogeneous synorogenic sequence of interbedded conglomerate, sandstone, and mudstone defined by Carr (1980) in exposure in the Goodsprings mining district. Underlain by an inferred unconformity (Carr and Pinkston, 1987). Unit originally assigned Late Jurassic to Early Cretaceous(?) age based on conventional $\mathrm{K}$-Ar dates of volcanic rocks within unit, but new laser fusion ${ }^{40} \mathrm{Ar} /{ }^{39} \mathrm{Ar}$ methods yielded a late Early Cretaceous age (99.0+0.4 Ma) (Fleck and Carr, 1990; Fleck and others, 1994); this date constrains the maximum age of movement on the Keystone thrust in the eastern Spring Mountains. Unit from 5 to $20 \mathrm{~m}$ thick

Ja Aztec Sandstone (Jurassic)—Exposed in eastern Spring Mountains. Tan and red quartz sandstone. Conspicuous 5-10-meter scale cross-bedding. Unit is truncated by the Keystone thrust fault. Thickness ranges from 650 to 800 meters (Longwell and others, 1965; Page and others, in press)

Rc Chinle Formation (Upper Triassic) — Exposed in eastern Spring Mountains. Interbedded sandstone, siltstone, shale, and minor conglomerate and limestone beds. Gypsum locally in discontinuous beds and irregular lenses. Base of formation is Shinarump Member, composed of conglomerate with distinctive reddish-brown and yellowish-brown chert clasts, and minor carbonate clasts. Unit conformably underlies Aztec Sandstone (Ja) and unconformably overlies Moenkopi Formation (Longwell and others, 1965; Stewart, 1980; Page and others, in press). Unit is 180 $\mathrm{m}$ thick

k $\mathbf{m}$ Moenkopi Formation (Middle? and Lower Trias sic)_Exposed in eastern Spring Mountains. In descending order, unit includes upper red member, Virgin Limestone Member, lower red member, and Timpoweap Member. Upper red member (Burchfiel and others, 1974) consists of claystone, mudstone, dolomite, limestone, siltstone, shale, and some gypsum. Virgin Limestone Member consists of bioclastic limestone, sandy limestone, dolomite, calcareous sandstone, and siltstone; fossils include brachiopods, gastropods, pelecypods, and pelmatozoan fragments; limestone locally contains ooids. Lower red member consists of siltstone, sandstone, shale, and minor dolomitic limestone, silty limestone, and gypsiferous siltstone beds. Timpoweap Member marks base of formation and is limestone and chertclast conglomerate with minor pebbly carbonate and calcareous sandstone beds; grades upward into lower redbed sequence. Unit is $585 \mathrm{~m}$ thick (Page and others, in press)

Pzu Sedimentary rocks, undivided (Paleozoic) — Unit mapped in Cottonwood Mountains, Hunter Mountain area, Grapevine Mountains north of Scotty's Castle, and the Reveille Range. Consists of undivided marine sedimentary rocks (Jennings, 1961; Jennings and others, 1962; Strand, 1967; Cornwall, 1972; Streitz and Stinson, 1974)

Pkt Kaibab and Toroweap Formations, undivided (Lower Permian)_Exposed in eastern Spring Mountains. Harrisburg and Fossil Mountain Members of the Kaibab Formation are recognized (Carr, 1992; Carr and McDonnell-Canan, 1992). Harrisburg Member is micritic limestone and dolomite, bedded gypsum, and some red shale and claystone; pectinoid valves and pelmatozoan ossicles observed; common chert in nodules and layers. Fossil Mountain Member is thick-bedded fossiliferous limestone and dolomitic limestone with brownweathering chert layers and nodules; includes brachiopods, bryozoans, and pelmatozoan columnals. Woods Ranch, Brady Canyon, and Seligman Members of the Toroweap are recognized (Carr, 1992; Carr and McDonnell-Canan, 1992); Woods Ranch Member is shale, dolomite, siltstone, and some gypsum. Brady Canyon Member is limestone and dolomitic limestone with common chert nodules and layers. Seligman Member is siltstone, sandstone, and gypsum; some dolomite and dolomitic sandstone in upper part. Unit forms ledgy to massive 
cliffs and is overlain unconformably by Timpoweap Member of the Moenkopi Formation; in places, unit is completely removed along this unconformity, and Timpoweap Member rests directly on Permian redbeds. Combined thickness of the two formations is 0-300 $\mathrm{m}$ in the eastern Spring Mountains (Page and others, in press)

Pr Redbeds (Lower Permian)_Exposed in eastern Spring Mountains. Consists of sandstone and some interbedded shale and siltstone; locally gypsiferous. Conformably overlies the Bird Spring Formation; contact with overlying Toroweap Formation is sharp and disconformable. Unit forms ledgy slope and is about $580 \mathrm{~m}$ thick (Longwell and others, 1965; Carr and Pinkston, 1987; Page and others, in press)

Pov Owens Valley Group (Lower Permian)_Exposures in the Dry Mountain area consist of the Lone Pine Formation, composed of thin-bedded calcereous mudstone, shale, and siltstone. Exposures in the Cottonwood Mountains and Panamint Range consist of the Darwin Canyon Formation, composed of well-bedded very fine grained sandstone, calcarenite sandstone, and subordinate calcarenitic, bioclastic limestone, and limestone conglomerate underlain by the Osborne Canyon Formation, composed of calcereous mudstone, bioclastic limestone, limestone conglomerate, and subordinate calcareous siltstone (Burchfiel, 1969; Stone, 1984; Stone and Stevens, 1987; Stone and others, 1987). The Osborne Canyon Formation and underlying Tihvipah Limestone have been incorrectly mapped as the Keeler Canyon Formation by Streitz and Stinson (1974) within the map area (Stone and others, 1987). Hall (1971) reported $730 \mathrm{~m}$ of unit exposed in Panamint Range area but Stone (1984) remapped much of this unit as Bird Spring Formation, and Burchfiel (1969) reported $180 \mathrm{~m}$ of the unit in the Dry Mountain area.

\section{PSu Sedimentary rocks, undivided (Permian to Sil} urian)_Exposed in southwestern part of map area. In Grapevine Mountains, Awawatz Mountains, and Slate Range consists of rocks correlative with parts of the Owens Valley Group, Keeler Canyon Formation, Perdido Group, Tin Mountain Limestone, Lost Burro Formation, and Hidden Valley Dolomite from top to bottom. In Funeral Mountains and northern Panamint Range consists of rocks correlative with parts of the Owens Valley Group, Bird Spring Formation, Indian Springs Formation, Santa Rosa Hills Limestone, Stone Canyon Limestone, Tin Mountain Limestone, Lost Burro Formation, and Hidden Valley Dolomite from top to bottom. About 2,370 m thick

PPMb Bird Spring (Lower Permian and Pennsylvanian) and Indian Springs Formations (Upper Missis sippian)_Exposed in eastern part of the map area in the Spring Mountains, Las Vegas Range, Sheep Range, Pahranagat Range, and Timpahute Range and in the western part of the map area in the Cottonwood Mountains and Panamint Range (included in PSu in this area). Bird Spring Formation consists of limestone, silty limestone, dolomite, chert, quartzite, siltstone, and shale. Common layers and nodules of brown-weathering chert. Contains abundant macrofossils including brachiopods, ostracods, colonial and solitary corals, bryozoans, sponges, pelmatozoan fragments, and fusulinids. In Las Vegas Range, Sheep Range, and part of the Spring Mountains, unit includes a distinctive carbonate slope to basin marker unit with submarine debrisflow conglomerates-marker unit is about $1,000 \mathrm{~m}$ above the base of the formation in the region. The underlying Indian Springs Formation of Webster and Lane (1967) consists of interbedded limestone, shale, and quartzite (Page and others, in press). Unit is from 1,300 to 2,355 m thick in the Spring Mountains; maximum thickness of 2,500 $\mathrm{m}$ in the Las Vegas Range; top not exposed (Page and others, in press)

PPt Tippipah Limestone (Lower Permian and Pennsylva nian)_Exposed in Nevada Test Site area. Consists of thin-bedded, fossiliferous limestone with chert nodules, calcareous siltstone to sandstone, and minor chert-pebble conglomerate, sandy limestone, and quartz sandstone. The clastic component increases up section. Top of unit unconformably overlain by younger Mesozoic and Cenozoic units. Unit unconformably overlies the Scotty Wash Quartzite (mapped as Msc) which is completely removed in some locations. Correlative with part of the Bird Spring Formation (PPMb). Maximum thickness about 1,250 m (Tschanz and Pampeyan, 1970; Kleinhampl and Ziony, 1985; Slate and others, 2000)

PPkc Keeler Canyon Formation (Lower Permian to Mid dle Pennsylvanian)_Exposed in the Dry Mountain area. Composed of silty, bioclastic limestone and siltstone and a basal micritic limestone with abundant chert nodules; fossils include fusulinids, pelmatozoans, bryozoans, and brachiopods. Unit is differentiated from the partly age-equivalent Bird Spring Formation by an abundance of turbidite facies. Conformably overlain by the Lone Pine Formation and conformably underlain by the Rest Spring Shale. (Ross, 1967; Streitz and Stinson, 1974; Stone and Stevens, 1987). Unit 1,164 m thick in Dry Mountain area (Burchfiel, 1969)

Mu Sedimentary rocks, undivided (Upper and Lower Mississippian)_-Mapped mostly in Cottonwood Mountains and Last Chance Range, Inyo County, California, and also in the Spotted Range, Lincoln and Clark Counties, Nevada. In Spotted Range, includes, from top to base, Indian Springs Formation of Webster and Lane (1967), Limestone of Timpi Canyon, Mercury Limestone, and Narrow Canyon Limestone (Poole and others, 1961; Stevens 
and others, 1996). Lower Mississippian rocks are correlative with parts of the Monte Cristo Group and Joana Limestone. Indian Springs Formation is mostly of variegated shale, but also has bioclastic limestone and quartzite beds; fossils include the biostratigraphically diagnostic Chesterian brachiopod Rhipidomella nevadensis. Limestone of Timpi Canyon, and the Mercury and Narrow Canyon Limestones, consist of limestone and dolomite, silty limestone, sandstone and quartzite, and shale; fossils include gastropods, pelmatozoan fragments, and brachiopods. Unit about $230 \mathrm{~m}$ thick (Longwell and others, 1965; Stevens and others, 1996).

Exposures in the Cottonwood Mountains are equivalent to the Monte Cristo Group as described below (Stone, 1984). In the Last Chance Range, unit includes Rest Spring Shale, Kearsarge Formation, Perdido Group, and Tin Mountain Limestone. Rest Spring Shale is thin-bedded, micritic limestone and black fissile shale; limestone is bioclastic and phosphatic (Stevens and others, 1996). Mexican Spring Formation of Perdido Group is mostly siltstone and conglomerate; siltstone is bioturbated and contains turbidite beds with graded bioclasts (brachiopods, gastropods, foraminifera); the underlying Leaning Rock Formation is thin-bedded, micritic, argillaceous limestone, and minor mudstone and conglomerate. Tin Mountain Limestone is limestone with distinctive pale-reddish-purple partings. Entire assemblage is $400 \mathrm{~m}$ thick in the Dry Mountain area of the Cottonwood Mountains (Burchfiel, 1969), about $140 \mathrm{~m}$ thick in the Panamint Range (Hall, 1971), and as great as $420 \mathrm{~m}$ thick in the Quartz Spring area, Inyo County (Stevens and others, 1996)

Msc Scotty Wash Quartzite (Upper Mississippian) and Chainman Shale (Upper and Lower Mississip pian), undivided-Exposed in the Timpahute Range, Pahranagat Range, and eastern Nevada Test Site area (Syncline Ridge, CP Hills, and Calico Hills). Scotty Wash Quartzite consists of tabular to lensoidal quartzite beds and fossiliferous limestone. Chainman Shale is black pyritic shale with sparse siltstone partings interbedded with thicker siltstone, sandstone, and bioclastic limestone beds. Forms strike valleys. East of the Nevada Test Site area, unit is poorly exposed, and thickness is estimated at more than 1,200 $\mathrm{m}$ (Trexler and others, 1996); unit is about $300 \mathrm{~m}$ thick in the Spotted and Pahranagat Ranges (Tschanz and Pampeyan, 1970)

Mm Monte Cristo Group (Upper and Lower Mississip pian)_Exposed in the Nopah Range, Montgomery Mountains, Spring Mountains, southern Las Vegas Range, southern Sheep Range, and in the Indian Springs area, south of U.S. Highway 95. Includes following formations, from top to base: Yellowpine Limestone, Bullion Limestone, Anchor Limestone, and Dawn Limestone. Formations consist of bioclastic limestone with pelmatozoan fragments, solitary and colonial corals, and brachiopods, and minor dolomite and chert beds. Yellowpine contains unusually large solitary rugose corals; also contains Lithostrotionella colonial corals, and pelmatozoan ossicles. Encrinitic limestone (grainstone to wackestone) typifies the Bullion Limestone.

Anchor Limestone consists of alternating thin-bedded limestone and chert beds. Dawn Limestone is abundantly fossiliferous and has common darkbrown-weathering chert beds. Unit is from 300 to $480 \mathrm{~m}$ thick (Burchfiel and others, 1983a, b; Page and others, in press)

MDe Eleana Formation (Mississippian and Upper Devo nian)_Exposed in Nevada Test Site area. Described by Poole and others (1961); reinterpreted by Trexler and others (1996). Sandstone, pebble conglomerate, siliceous siltstone, and minor bioclastic limestone and bedded chert. Unit varies laterally and vertically and was deposited in deepwater turbiditic trough and submarine fan depositional environments. Upper $150 \mathrm{~m}$ consists of interbedded bioclastic limestone and chert-litharenite sandstone. Middle 1,700 m consists of chert-litharenite sandstone, conglomerate, and siltstone. Lower $170 \mathrm{~m}$ consists of debris-flow conglomerate deposits, silty and sandy limestone, and quartzite. Top of unit is everywhere truncated by the Belted Range thrust (Cole and Cashman, 1999). Unit maximum thickness is $2,040 \mathrm{~m}$

Mj Joana Limestone (Lower Mississippian)_Exposed in northeastern part of map area in the Pahranagat and Timpahute Ranges. Limestone with interbedded silty limestone, shale, and chert; upper part weathers to lighter shades of gray and contains more chert and shale beds; lower part generally forms massive limestone cliffs; abundant pelmatozoan fragments and corals (Tschanz and Pampeyan, 1970). Correlative with lower part of Monte Cristo Group (Mm), and lower part of Mississippian undivided unit (Mu). About 200 to $300 \mathrm{~m}$ thick

MDu Sedimentary rocks, undivided (Lower Mississippian and Upper and Middle Devonian)_Exposed in eastern part of the map area in Lincoln and Clark Counties and parts of eastern Nye County. In Keystone thrust plate (eastern Spring Mountains) includes the Sultan Limestone. In western thrust plates of Spring Mountains and majority of Lincoln and Clark Counties, includes Guilmette Formation and either the Crystal Pass Member of the Sulton Limestone or the Pilot Shale to the south or north of the Las Vegas Valley shear zone, respectively. Unit is partly correlative with the Devils Gate Limestone as mapped by Burchfiel (1965) and Burchfiel and others $(1974 ; 1983 a, b)$ in the Specter Range, Spring Mountains, Montgomery Mountains, and Nopah and Resting Spring Ranges. Guilmette Formation is dolomite, limestone, and dolomitic 
quartzite. Limestone and dolomite in upper part of the formation are generally micritic, and beds are cyclic, laminated, and burrow mottled. Dolomitic quartzite beds are in upper part of formation. Middle part of formation is mostly cliff-forming dolomite with abundant stromatoporoid biostromes and patch reefs; also contains Amphipora sp., gastropods, and brachiopods. Lower part of formation forms ledgy slope beneath cliff-forming dolomite and contains thin-bedded limestone with stromatoporoids alternating with yellowish-gray weathering dolomicrite. Lower part is "yellow bed" of Guilmette (Tschanz and Pampeyan, 1970) which marks the base of the formation in much of eastern Nevada. Map unit is 380-520 m thick in the Spring Mountains, $630 \mathrm{~m}$ thick in the southern Sheep Range, 730-990 m thick in the Pahranagat Range, 670-750 m thick in the Spotted and Desert Ranges, and $350 \mathrm{~m}$ thick in the Nevada Test Site area (Slate and others, 2000). Sultan Limestone (Hewett, 1931) consists, from top to base, of the Crystal Pass, Valentine, and Ironside Members. Crystal Pass Member is partly Mississippian and is light-grayweathering micritic limestone (Page and others, in press). Valentine and Ironside Members are thin- to thick-bedded limestone and dolomite with silicified stromatoporoids. Sultan Limestone is $175-200 \mathrm{~m}$ thick (Page and others, in press)

Dlb Lost Burro Formation (Upper and Middle Devo nian)_Exposed in Cottonwood Mountains and Panamint Range. Uppermost $10 \mathrm{~m}$ of unit includes calcareous, laminated to thin-bedded sandstone and sandy dolomite (Quartz Spring Sandstone Member). Remainder of unit consists of dolomite and limestone, sandy dolomite, quartzite and sandstone beds; dolomite and limestone beds contain Amphipora sp. and silicified stromatoporoids. Includes quartzitic basal Lippincott Member. Included within map unit PSu in Panamint Range and southeastern Funeral Mountains. Correlative with parts of the Guilmette Formation and Sultan Limestone. Unit about $500 \mathrm{~m}$ thick in the Dry Mountain area (Burchfiel, 1969) and $457 \mathrm{~m}$ thick in the Panamint Range (Hall, 1971)

D€d Dolomite and limestone, undifferentiated (Devonian to Upper Cambrian) —Exposed only in northern Nye County, in the Reveille and Quinn Canyon Ranges. Includes, from top to base, rocks correlative with parts of the Guilmette Formation, Simonson Dolomite, Sevy Dolomite, Laketown Dolomite, Ely Springs Dolomite, Eureka Quartzite, and Pogonip Group; thickness unknown

Dsf Slope-facies carbonate rocks (Upper to Lower Devo nian)_Exposed at Bare Mountain, Calico Hills, Ranier Mesa, and Carbonate Wash areas of Nevada Test Site. Unit consists of limestone, dolomite, and silty carbonate rocks. Contains submarine debrisflow conglomerate; clasts composed of quartzite, limestone, dolomite, and chert. Maximum thickness is $300 \mathrm{~m}$ (Slate and others, 2000)

Ds Simonson Dolomite (Middle Devonian)_Exposed in eastern part of the map area in Lincoln, Clark, and parts of Nye Counties. Includes mostly finely crystalline dolomite; contains abundant stromatoporoids and Amphipora sp.; in some locations (northwestern Spring Mountains, Pahranagat Range), upper beds of the Simonson contain the Givetian brachiopod Strigocephalus sp. In much of Lincoln and Clark Counties, base of formation is marked by distinctive quartzite unit which unconformably overlies the Sevy Dolomite. Unit is partly correlative with the Nevada Formation as mapped by Burchfiel and others (1974) in the Spring Mountains, and Burchfiel and others (1983a, b) in the Montgomery Mountains and Nopah Range. Unit is $120 \mathrm{~m}$ thick in northwest Spring Mountains, $190 \mathrm{~m}$ thick in the southern Sheep Range, $365 \mathrm{~m}$ thick in the Pahranagat Range, and $300 \mathrm{~m}$ thick in the Nevada Test Site area (Slate and others, 2000)

DSu Sedimentary rocks, undivided (Devonian and Sil urian)-Mapped in Lee Canyon and Deer Creek thrust plates, central Spring Mountains (Page and others, in press). Unit includes strata below basal yellow-bed sequence of Guilmette Formation (Devonian) and above Ely Springs Dolomite (Upper Ordovician). These rocks are equivalent with parts of the Simonson Dolomite, Sevy Dolomite, and Laketown Dolomite. Unit is 60-80 m thick

D€m Mountain Springs Formation (Middle Devonian, Lower Ordovician, and Upper Cambrian)Mapped only in eastern Spring Mountains. Defined by Gans (1974) and subsequently modified by Miller and Zilinsky (1981) and Page and others (in press). Subdivided into three informal members from top to base (Page and others, in press): upper member restricted to Middle Devonian strata equivalent to part of the Simonson Dolomite, and consists of cycles of finely to coarsely saccharoidal dolomite and dolomudstone with scattered rip-up clasts. Contains pentamerid brachiopods, stromatoporoids, and more rarely, bryozoan, coral, and pelmatozoan fragments. Middle member is early Late Ordovician age, is equivalent to part of the Ely Springs Dolomite, and is burrow-mottled, bioclastic dolopackstone. Lower member is Early Ordovician in age and equivalent to part of the Pogonip Group. Member is burrowed, dolomitized wackestone, packstone, and mudstone, and contains gastropods (Palliseria sp. and Maclurities sp.) and sponges (Recptaculites sp.). Unit is $295 \mathrm{~m}$ thick

DEu Mountain Springs (Middle Devonian, Lower Ordovi cian, and Upper Cambrian) and Nopah Forma tions (Upper Cambrian), undivided-Mapped only in eastern Spring Mountains in southeastern part of area. Unit is about $600 \mathrm{~m}$ thick 
DSsI Sevy (Middle and Lower Devonian) and Laketown (Upper and Middle Silurian) Dolomites, undi vided-In most parts of Lincoln and Clark Counties (Desert, Pintwater, Sheep, Spotted, Pahranagat and Timpahute ranges, and Worthington Mountains), Sevy Dolomite is cliff-forming, light-gray, aphanitic dolomite containing thin beds of cross-bedded sandy dolomite and dolomitic quartzite; lacks macrofossils; top of Sevy marked by cherty argillaceous unit composed of siltstone and cherty aphanitic dolomite; this unit was originally defined as an informal member of the Sevy Dolomite (Osmond, 1962), but was later redefined as a separate map unit (Johnson and others, 1989); overlain unconformably by Simonson Dolomite. Combined Sevy Dolomite and cherty argillaceous unit is $275 \mathrm{~m}$ thick in the Nevada Test Site area (Slate and others, 2000), and its maximum thickness is nearly $500 \mathrm{~m}$ in the Pahranagat Range (Reso, 1963).

Laketown Dolomite underlies Sevy Dolomite in Lincoln and Clark Counties where it displays typical tri-part character widely recognized in the eastern Great Basin-upper dark, middle light, and lower dark dolomite parts. Upper dark part is mostly finely saccharoidal dolomite containing brachiopods, halysitid corals, and pelmatozoan ossicles. Middle part is massive dolomite that contains silicified pentamerid brachiopods. Lower part is saccharoidal dolomite with brachiopods, corals, pelmatozoan ossicles, and stromatoporoids; also contains beds and nodules of dark-brown-weathering chert. Laketown Dolomite unconformably overlies Ely Springs Dolomite. The Laketown Dolomite is $250 \mathrm{~m}$ thick in the Nevada Test Site area, and reaches a maximum thickness of $285 \mathrm{~m}$ in the Pahranagat Range

DSIm Lone Mountain Dolomite (Lower Devonian and Sil urian)—Exposed only at Bare Mountain. Fine- to medium-crystalline dolomite; pelmatozoan fragments are common. Contact with underlying Roberts Mountain Formation gradational. Unit is about $490 \mathrm{~m}$ thick (Cornwall and Kleinhampl, 1961)

DShv Hidden Valley Dolomite (Lower Devonian and Sil urian)-Mapped in the Cottonwood and Funeral Mountains; included with unit PSu in the Nopah and Panamint Ranges and Montgomery Mountains. Consists mostly of massive dolomite, but includes minor quartzite beds and brown-weathering chert at base in the Panamint Range area (Hall, 1971). Generally lacks macrofossils but age equivalent with parts of the Sevy and Laketown Dolomites based on fossils collected by McAllister (1952). Contact with underlying Ely Springs Dolomite is gradational. Unit is 440-460 m thick in southeastern Funeral Mountains (McAllister, 1974) and in the Dry Mountain area (Burchfiel, 1969), about 120 m thick in Panamint Range, and about $100 \mathrm{~m}$ thick in the Nopah Range (Burchfiel and others, 1983a, b)
Sr

Roberts Mountains Formation (Silurian)—Exposed only at Bare Mountain. Dolomite and limestone, and minor interbedded silty and sandy dolomite, dolomite pebble-conglomerate, and dark-brownweathering chert nodules and layers. Contains brachiopods, corals, graptolites, and conodonts of Late to Early Silurian age (Slate and others, 2000). Contact with underlying Ely Springs Dolomite is disconformity. Unit is $200 \mathrm{~m}$ thick (Monsen and others, 1992)

Opa Palmetto Formation (Upper, Middle, and Lower Ordovician)—Exposed in western part of map area in Palmetto Mountains, Magruder Mountain, and Silver Peak Range. Mostly shale and siltstone, but also includes thin-bedded chert, limestone, and quartzite; quartzite beds are more common in lower part. Rocks are commonly metamorphosed to hornfels. Shale contains Middle Ordovician graptolites (Albers and Stewart, 1972; McKee, 1985). Collections by Albers and Stewart (1972) from the southern Silver Peak Range yielded Late Ordovician fossils and from the Goldfield area yielded Early Ordovician fossils. Unit is deep-water facies (eugeosynclinal) and interpreted as allochthonous with respect to the Roberts Mountain thrust (Albers and Stewart, 1972; McKee, 1985); upper and lower unit contacts are nearly everywhere represented by faults; maximum thickness estimated at about $600 \mathrm{~m}$

o€u Sedimentary rocks, undivided (Ordovician and Upper Cambrian)-Mapped in southern part of area in Nopah Range, Montgomery Mountains, Panamint Range, Grapevine and Funeral Mountains, Cottonwood Mountains, and Last Chance Range. Includes parts of the Ely Springs Dolomite, Eureka Quartzite, and Pogonip Group. Unit is about $720 \mathrm{~m}$ thick in the Dry Mountain area (Burchfiel, 1969) and in the Panamint Range area (Hall, 1971), and about 610 m thick in the Nopah Range (Burchfiel and others, 1983a, b)

Oee Ely Springs Dolomite (Upper Ordovician) and Eureka Quartzite (Upper and Middle Ordovician), undivided

Oes Ely Springs Dolomite (Upper Ordovician) —Widely exposed in map area. Upper $20-25 \mathrm{~m}$ consists of slope-forming, finely crystalline dolomite with sparse pelmatozoan fragments. Most of the Ely Springs (lower two thirds to three quarters) is cliffforming, burrow-mottled, irregularly thin- to thickbedded dolomite with common planar laminations; includes nodules and lenses of dark-gray to darkbrown chert. Fossils include brachiopods, colonial (Halysites sp. and favositids) and solitary corals, gastropods, pelmatozoan ossicles, and stromatoporoids. Lower contact with Eureka Quartzite is disconformity; upper contact with Laketown Dolomite (Silurian) in eastern part of map area is disconformable; in western part of map area, upper contact 
with Hidden Valley Dolomite is gradational and conformable (Hall, 1971). Unit is 50-200 m thick

Oe Eureka Quartzite (Upper and Middle Ordovician)Widely exposed in map area. Consists of fine- to medium-grained orthoquartzite and sandstone.

Beds contain tabular-planar and trough crossbed sets and Skolithos burrows. At some locations, as in the Spring Mountains, has sandy carbonate beds and collophane nodules (Ross, 1964), and in Panamint Range area, lower part contains silty and sandy dolomite, argillaceous quartzite, and minor shale. Unit is 6-150 m thick

O€pn Pogonip Group (Middle and Lower Ordovician and Upper Cambrian) and Nopah Formation (Upper Cambrian), undivided-Mapped in parts of the Nopah Range, Spring Mountains, Quinn Canyon Range, and southernmost Monitor Range

O€p Pogonip Group (Middle and Lower Ordovician and Upper Cambrian)_-Widely exposed across map area. Consists of (from top to base) the Antelope Valley Limestone, Ninemile Formation, and the Goodwin Limestone (Byers and Barnes, 1967; Ross, 1964). Antelope Valley Limestone is finely to coarsely crystalline limestone and silty limestone; beds are commonly burrowed and have yellowishorange to pale-red tracks and trails on bedding planes; contains orthocone cephalopods, gastropods (Maclurites sp. and Palliseria sp.), pelmatozoans, Receptaculites sp., and trilobites; also contains ooids and oncoids. Ninemile Formation is shaly siltstone, silty limestone, and dolomite. Goodwin Limestone is limestone and dolomite with darkbrown-weathering chert layers and distinctive intraclastic conglomerate; contains trilobite and brachiopod fragments and sparse ooids. Base of Goodwin contains Late Cambrian conodonts in the Spring Mountains and southern Sheep Range (Page and others, in press). Ninemile Formation is absent in most locations in the eastern part of the map area (Lincoln and Clark Counties). Group is about 410 $\mathrm{m}$ thick in the Dry Mountain area (Burchfiel, 1969), $384 \mathrm{~m}$ thick in the Panamint Range (Hall, 1971), $320 \mathrm{~m}$ thick in Nopah Range (Burchfiel and others, 1983a, b), 360-700 m thick in the Spring Mountains and southern Sheep Range, (Page and others, in press), $957 \mathrm{~m}$ thick in the Pahranagat Range (Tschanz and Pampeyan, 1970), and 1,050 m thick in Nevada Test Site area (Slate and others, 2000)
Emigrant Formation (Upper and Middle Cam brian)_Exposed in Esmeralda County, Goldfield Hills, Palmetto Mountains, Clayton Valley, and Montezuma Range areas. Consists of an upper limestone and siltstone member, a middle shale member, and lower limestone and chert member. Upper member is interbedded limestone and siltstone; contains sponge spicules and phosphatic brachiopod shells. Middle shale member is olive-gray to greenish-gray shale. Lower member is interbedded limestone and laminated chert, and some intraclastic conglomerate; trilobites common in Magruder Mountain area (McKee, 1985). Unit is 1,524-1,828 m thick (Albers and Stewart, 1972)

€u Sedimentary rocks, undivided (Upper to Lower Cambrian)_-Mapped in the Last Chance Range and Cottonwood Mountains. In Last Chance Range, northwest of the Cucomongo fault, includes rocks equivalent with parts of the Emigrant, Mule Spring, Harkless, Poleta, and Campito Formations.

Southeast of the Cucomongo fault in the Last Chance Range and Cottonwood Mountains, includes rocks equivalent with parts of the Nopah, Bonanza King, Carrara, Zabriskie, and Wood Canyon Formations (McKee, 1985)

€nb Nopah (Upper Cambrian) and Bonanza King For mations (Upper and Middle Cambrian), undi vided-Mapped in the west-central Pintwater Range; thickness unknown

€n Nopah Formation (Upper Cambrian)_Widely exposed in map area. In central part of the map area unit includes, from top to base, Smoky, Halfpint, and Dunderberg Shale Members. Smoky and Halfpint Members consist of alternating light- to darkgray cliff-forming dolomite that gives these rocks a banded appearance; members contain common stromatolites, oncoids, and brachiopod fragments, and less common pelmatozoan fragments. Dunderberg Shale Member consists of thin-bedded silty limestone, shale, and some siltstone; Dunderbergia sp. trilobite fragments are common. Formation is about 345-380 m thick in the Spring Mountains and southern Sheep Range (Page and others, in press), $365 \mathrm{~m}$ thick in the northern Last Chance Range (McKee, 1985), $457 \mathrm{~m}$ thick in the Panamint Range area (Hall, 1971), about $530 \mathrm{~m}$ thick in the Nopah Range and in the Cottonwood Mountains (Burchfiel and others, 1983a, b; Burchfiel, 1969), 766 m thick in the Pahranagat Range (Reso, 1963), and 720 m thick in the Nevada Test Site area (Slate and others, 2000)

€nbc Nopah (Upper Cambrian), Bonanza King (Upper and Middle Cambrian), and Carrara Formations (Middle and Lower Cambrian), undividedMapped in the Quinn Canyon, Nopah, Kingston, Resting Springs, Montgomery, Greenwater, Panamint, Funeral, and Grapevine ranges

€b Bonanza King Formation (Upper and Middle Cam brian)-Banded Mountain and Papoose Lake Members recognizable in most parts of the map area. Partly correlative with the Highland Peak Formation in Lincoln County (Tschanz and Pampeyan, 1970). Banded Mountain Member is fine- to medium crystalline dolomite and limestone; alternating light- to dark-gray colors of beds give the member a distinctive banded appearance. Orange burrow mottling is prevalent, and several layers have dark-brown-weathering chert beds and nodules. Base of the member is marked by the regionally 
extensive "silty unit" (Barnes and Palmer, 1961; Guth, 1980; Gans, 1974). The underlying Papoose Lake Member is dolomite with distinctive orange burrow mottles; sparse limestone and silty dolomite beds. Formation is 580-1,700 $\mathrm{m}$ thick in the Nevada Test Site area (Slate and others, 2000), about 1,000 $\mathrm{m}$ thick in the Dry Mountain area (Burchfiel, 1969), 1,150-1,350 m thick in the Montgomery Mountains and Nopah Range, respectively (Burchfiel and others, 1983a, b), about $610 \mathrm{~m}$ thick in the northern Last Chance Range (McKee, 1985), 445-900 m thick in the Spring Mountains and southern Sheep Range (Page and others, in press), and reaches a maximum thickness of 1,633 $\mathrm{m}$ in the Groom Range area, Lincoln County (Tschanz and Pampeyan, 1970)

€c Carrara Formation (Middle and Lower Cam brian)_-Interbedded limestone, silty limestone, siltstone, sandstone, and shale. Upper part is mostly cliff-forming silty limestone, and lower part contains mostly clastic rocks. Limestone beds contain ooids, oncoids, and stromatolites. Contact with overlying Bonanza King Formation is commonly marked by a change from slope-forming limestone of the Carrara to more massive cliff-forming limestone and dolomite of the Bonanza King Formation. Unit is $457 \mathrm{~m}$ thick in the northwestern Spring Mountains (Vincellette, 1964), $500 \mathrm{~m}$ thick in the Striped Hills, $350 \mathrm{~m}$ thick at Bare Mountain (Slate and others, 2000), and $420 \mathrm{~m}$ thick in the Montgomery Mountains (Burchfiel and others, 1983a, b)

€ms Mule Spring Limestone (Lower Cambrian)Exposed in Palmetto Mountains, Clayton Ridge, Goldfield Hills, and Montezuma Range. Thin- to medium-bedded, aphanitic to finely-crystalline limestone with trilobite fragments; thicker beds have oncoids; calcareous siltstone and silty limestone are in lower part. Contact with overlying Emigrant Formation is sharp and disconformable. Total thickness estimated at 120-150 m (Albers and Stewart, 1972)

€h Harkless Formation (Lower Cambrian)_Exposed mostly in Esmeralda County, Nevada. Upper member is siliceous siltstone and shale. Lower member is interbedded sandstone, siltstone and thin-bedded limestone. Unit contains Olenellid trilobites and archaeocyathids, especially in lower member. Conformable with overlying Mule Spring Formation and underlying Poleta Formation; about 760-1,066 m thick (Albers and Stewart, 1972; McKee, 1985)

€z Zabriskie Quartzite (Lower Cambrian)_Laminated to thick-bedded orthoquartzite, commonly crossbedded and well-cemented; has skolithos. Unit is 30-350 $\mathrm{m}$ thick in the Nevada Test Site area (Slate and others, 2000), $70 \mathrm{~m}$ thick in the Montgomery Mountains (Burchfiel and others, 1983a, b), and 106 $\mathrm{m}$ thick in the Dry Mountain area

€Zws Wood Canyon Formation (Lower Cambrian and Late Proterozoic) and Stirling Quartzite (Late
Proterozoic), undivided-Mapped in the Resting Springs, Nopah, Kingston, and Panamint ranges, and Montgomery Mountains

$€ Z w$ Wood Canyon Formation (Lower Cambrian and Late Proterozoic)—Quartzite, sandstone, siltstone, shale, and dolomite. Shaly and silty units increase in abundance in the upper part of the formation. Upper and lower thirds of unit consist of interbedded quartzite, micaceous siltstone, and minor silty dolomite. Middle third is mostly quartzite and siltstone, and minor distinctive arkosic conglomerate (Slate and others, 2000). Locally metamorphosed to subgreenschist and lower greenschist facies south of Nevada Test Site in Funeral Mountains and Specter Range (Slate and others, 2000). Unit is from 700 to $1,150 \mathrm{~m}$ thick in the Nevada Test Site area (Slate and others, 2000), about $600 \mathrm{~m}$ thick in the Montgomery Mountains (Burchfiel and others, 1983a, b), and 640-820 m thick in the northwest Spring Mountains (Vincellette, 1964)

€po Poleta Formation (Lower Cambrian)_Exposed in the Montezuma Range, Magruder Mountain, and Palmetto Mountains in Esmeralda County, Nevada. Upper, middle, and lower informal members recognized. Upper member is thin-bedded limestone with some poorly preserved archaeocyathids. Middle member is phyllitic siltstone, limestone, and sandstone or quartzite. Olenellid trilobites common in siltstone, and archaeocyanthids in limestone. Contact with overlying Harkless Formation is sharp. Unit is greater than $600 \mathrm{~m}$ thick (McKee, 1985)

\section{Campito Formation (Lower Cambrian and Late} Proterozoic)_Exposed in Esmeralda County, Nevada. Divided into:

€cam Montenegro Member (Lower Cambrian) - Siltstone, shale, and sandstone. Olenellid trilobites and archaeocyathids are rare in the shaly units. Unit is $315 \mathrm{~m}$ thick (Albers and Stewart, 1972)

€Zcaa Andrews Mountain Member (Lower Cambrian and Late Proterozoic) — Thin-bedded quartzite and sparse beds of greenish shale. Sandstone is crossbedded, and has ripple marks and worm trails. About 910 m thick (McKee, 1985)

Deep Spring Formation (Late Proterozoic) Exposed in Esmeralda County, Nevada, where upper, middle, and lower members are recognized. Upper member is siltstone, quartzite, and minor dolomite. Middle member is oolitic-limestone, quartzite, and some dolomite. Lower member is limestone and dolomite, and some siltstone. Unit apparently conformable with overlying Campito Formation. About 487-548 m thick (Albers and Stewart, 1972; McKee, 1985) (Late Proterozoic)_-The Stirling Quartzite and Reed Dolomite are time-equivalent units with the 
Stirling Quartzite representing the eastern facies and the Reed Dolomite the western facies within the map area. These units are mapped as undivided due to similar hydrologic properties. The Stirling Quartzite contains quartzite and sandstone, conglomeratic quartzite, and minor beds of micaceous siltstone. Quartz grains are usually fine- to mediumgrained. A $20 \mathrm{~m}$ thick white quartzite marks the base of the unit in the Specter Range and northwestern Spring Mountains. Locally metamorphosed to subgreenschist and lower greenschist facies at Bare Mountain, Funeral Mountains (Slate and others, 2000), and parts of the northwestern Spring Mountains (Vincellette, 1964). Unit forms massive cliffs and is $975 \mathrm{~m}$ thick in northwestern Spring Mountains (Nolan, 1924; Vincellette, 1964), 1,100 m thick in the Montgomery Mountains (Burchfiel and others, 1983a, b), 2,100 m thick in the Funeral Mountains (Wright and Troxel, 1993), 1,500 m thick in the Belted Range, and 700 m thick at Bare Mountain (Slate and others, 2000; Stewart, 1974). The Reed Dolomite is exposed in Slate Ridge, Gold Mountain, Palmetto Mountain, and Magruder Mountain areas, Esmeralda County, Nevada, and parts of Inyo County, California. The Reed Dolomite contains medium to coarsely crystalline dolomite, sandy dolomite, and minor amounts of limestone, siltstone, and quartzite; contains ooids and locally is pelletal. Reed Dolomite is greater than 457 m thick (Albers and Stewart, 1972)

Johnnie and Wyman Formations, undivided (Late Proterozoic) - The Johnnie and Wyman Formations are time-equivalent units with the Johnnie representing the eastern facies and the Wyman, the western facies within the map area. These units are mapped as undivided due to similar hydrologic properties. The Johnnie Formation is exposed in the Nopah, Panamint, and Kingston Ranges and Spring and Funeral Mountains. Unit contains quartzite, conglomeratic quartzite, siltstone, shale, and minor limestone and dolomite beds. Upper part contains Rainstorm Member (Stewart, 1974), which can be traced regionally across parts of southern Nevada and southeastern California. Rainstorm Member contains mixed clastic and carbonate units and the "Johnnie oolite," a distinctive ooid-bearing dolomite unit in lower part of member. Formation exceeds $900 \mathrm{~m}$ thick in the Halfpint Range (Barnes and Christiansen, 1967), and is estimated at 2,000 $\mathrm{m}$ thick in the Funeral Mountains (Wright and Troxel, 1993); only $600 \mathrm{~m}$ of unit exposed in Spring Mountains (Vincellette, 1964). The Wyman Formation is exposed in the Slate Ridge and Gold Mountain areas of Esmeralda County and western parts of Inyo County, California. Unit contains phyllitic siltstone, limestone, sandy limestone, and calcareous sandstone. Maximum incomplete thickness of the Wyman Formation is $400 \mathrm{~m}$ (Albers and Stewart, 1972)
ZYp Pahrump Group (Late and Middle Proterozoic) Exposed in Black and Funeral Mountains and Panamint and Kingston Ranges of Death Valley region (Wright and others, 1974). Includes, from top to base, Kingston Peak, Beck Spring, and Crystal Spring Formations. Kingston Peak is staurolite- and biotitebearing pelitic schist, metaconglomerate, and calcitic marble; contains some basalt flows. Beck Spring is calcitic marble and minor dolomite. Crystal Spring is staurolite-biotite-bearing pelitic schist, micaceous quartzite, calcitic marble, and amphibolite; has diabase sills that were dated at $1.08 \mathrm{Ga}$ (Heaman and Grotzinger, 1992). Group is $1,570 \mathrm{~m}$ thick in Funeral Mountains (Wright and Troxel, 1993)

Xmi Metamorphic and igneous rocks, undifferentiated (Early Proterozoic)—Exposed mainly in the southern part of the map, in Greenwater, Funeral, Nopah, and Panamint Ranges, where it consists of biotite schist, biotite-hornblende-schist, and biotite-epidote schist. Schist is intruded by gneissic monzogranite in Trappman Hills, and north of western Gold Flat, schist and granite intruded by aplite and pegmatite dikes. Includes metasedimentary rocks in Funeral Mountains that are locally intruded by silicic plutons dated at $1.7 \mathrm{Ga}$ (Wright and Troxel, 1993)

\section{References Cited}

Abolins, M.J., 1999, I. Stratigraphic constraints on the number of discrete neoproterozoic glaciations and the relationship between glaciation and ediacaran evolution, II. The Kwichup Spring thrust in the northwestern Spring Mountains, Nevada: Implications for large-magnitude extension and the structure of the cordilleran thrust belt: Unpublished Ph.D. dissertation, California Institute of Technology, Pasadena, California, 348 p.

Albers, J.P., and Stewart, J.H., 1972, Geology and Mineral Deposits of Esmeralda County, Nevada: Nevada Bureau of Mines and Geology Bulletin 78, plate 1, scale 1:250,000.

Anderson, J.J., and Rowley, P.D., 1975, Cenozoic stratigraphy of the southwestern high plateaus of Utah, in Anderson, J.J., Rowley, P.D., Fleck, R.J., and Nairn, A.E.M., eds., Cenozoic geology of southwestern high plateaus of Utah: Geological Society of America Special Paper 160, p. 1-52.

Barnes, H., and Christiansen, R.L., 1967, Cambrian and Precambrian rocks of the Groom District, southern Great Basin, Nevada: U.S. Geological Survey Bulletin 1244-G, p. 1-34.

Barnes, H., Ekren, E.B., Rodgers, C.L., and Hedlund, D.C, 1982, Geologic and tectonic maps of the Mercury quadrangle, Nye and Clark Counties, Nevada: U.S. Geological Survey Miscellaneous Investigations Series Map I-1197, scale 1:24,000.

Barnes, H., and Palmer, A.B., 1961, Revision of stratigraphic nomenclature of Cambrian rocks, Nevada Test Site and vicinity, Nevada: U.S. Geological Survey Professional Paper 450-C, $100 \mathrm{p}$.

Beratan, K.K., Hsieh, J., and Murray, B., 1999, Pliocene-Pleistocene stratigraphy and depositional environments, southern Confidence 
Hills, Death Valley, California, in, Wright, L.A., and Troxel, B.W., eds., Cenozoic basins of the Death Valley region: Geological Society of America Special Paper 333, p. 289-300.

Best, M.G., Christiansen, E.H., and Blank, R.H., Jr., 1989a, Oligocene caldera complex and calc-alkaline tuffs and lavas of the Indian Peak volcanic field, Nevada and Utah: Geological Society of America Bulletin, v. 101, p. 1076-1090.

Best, M.G., Christiansen, E.H., Deino, A.L., Gromme, C.S., McKee, E.H., and Noble, D.C., 1989b, Excursion 3a-Eocene through Miocene volcanism in the Great Basin of the western United States: New Mexico Bureau of Mines and Mineral Resources Memoir 47, p. 91-133.

Best, M.G., Christiansen, E.H., Deino, A.L., Gromme, C.S., and Tingey, D.G., 1995, Correlation and emplacement of a large, zoned, discontinuously exposed ash-flow sheet- $\mathrm{The}{ }^{40} \mathrm{Ar} /{ }^{39} \mathrm{Ar}$ chronology, paleomagnetism, and petrology of the Pahranagat Formation, Nevada: Journal of Geophysical Research, v. 100, no. B12, p. $24,593-24,609$.

Best, M.G., Scott, R.B., Rowley, P.D., Swadley, WC, Anderson, R.E., Gromme, C.S., Harding, A.E., Deino, A.L., Christiansen, E.H., Tingey, D.G., and Sullivan, K.R., 1993, Oligocene-Miocene caldera complexes, ash-flow sheets, and tectonism in the central and southeastern Great Basin, in Lahren, M.M., Trexler, J.H., Jr., and Spinosa, C., eds., Crustal evolution of the Great Basin and Sierra Nevada: Cordilleran/ Rocky Mountain Sections, Geological Society of America Guidebook, Department of Geological Sciences, University of Nevada Reno, p. 285-311.

Brady, R.H., III, 1986, Stratigraphy and tectonics of the northern Avawatz Mountains at the intersection of the Garlock and Death Valley fault zones, San Bernardino County, California, field guide, in, Troxel, B.W., ed., Quaternary tectonics of southern Death Valley: Field Guide, Pacific Cell, Friends of the Pleistocene 1986 annual meeting, p. 1-12.

Brady, R.H., III, and Troxel, B.W., 1999, The Miocene Military Canyon Formation: Depocenter evolution and constraints on lateral faulting, southern Death Valley, California, in, Wright, L.A., and Troxel, B.W., eds., Cenozoic basins of the Death Valley region: Geological Society of America Special Paper 333, p. 277-288.

Burchfiel, B.C., 1965, Structural geology of the Specter Range quadrangle, and its regional significance: Geological Society of America Bulletin, v. 76, p. 175-192.

Burchfiel, B.C., 1969, Geology of the Dry Mountain Quadrangle, Inyo County, California: California Division of Mines and Geology Special Report 99, 19 p., scale 1:62,500.

Burchfiel, B.C., Fleck, R., Secor, D.T., Vincellette, R.R., and Davis, G.A., 1974, Geology of the Spring Mountains, Nevada: Geological Society of America Bulletin, v. 85, p. 1013-1022.

Burchfiel, B.C., Hamill, G.S., IV, Wilhelms, D.E., 1983a, Geologic map with discussion of stratigraphy of the Montgomery Mountains and the northern half of the Nopah and Resting Spring Ranges, Nevada and California: Geological Society of America Map and Chart Series MC-44, scale 1:62,500.

Burchfiel, B.C., Hamill, G.S., IV, Wilhelms, D.E., 1983b, Structural geology of the Montgomery Mountains and northern half of the Nopah and Resting Spring Ranges, Nevada and California: Geological Society of America Bulletin, v. 94, p. 1359-1376.

Butler, P.R., Troxel, B.W., and Verosub, K.L., 1988, Late Cenozoic history and styles of deformation along the southern Death Valley fault zone, California: Geological Society of America Bulletin, V. 100, p. 402-410.
Byers, F.M., Jr., and Barnes, Harley, 1967, Geologic map of the Paiute Ridge quadrangle, Nye and Lincoln Counties, Nevada: U.S. Geological Survey Geologic Quadrangle Map G0-577, scale 1:24,000.

Calzia, J.P., Troxel, B.W., Wright, L.A., Burchfiel, B.C., Davis, G.A., and McMackin, M.R., 2000, Geologic map of the Kingston Range, southern Death Valley, California: U.S. Geological Survey Open-File Report 00-412, scale 1:31,680.

Carr, M.D., 1980, Upper Jurassic to Lower Cretaceous(?) synorogenic sedimentary rocks in the southern Spring Mountains, Nevada: Geology, v. 8, p. 385-389.

Carr, M.D., 1992, Bedrock geologic map of the Blue Diamond NE 7.5 quadrangle, Clark County, Nevada: U.S. Geological Survey OpenFile Report 92-263, scale 1:24,000.

Carr, M.D., and McDonnell-Canan, Cheryl, 1992, Bedrock geologic map of the Blue Diamond SE 7.5' quadrangle, Clark County Nevada: U.S. Geological Survey Open-File Report 92-177, scale 1:24,000.

Carr, M.D., and Pinkston, J.C., 1987, Geologic Map of the Goodsprings District, Southern Spring Mountains, Clark County, Nevada: U.S. Geological Survey Miscellaneous Field Studies Map MF-1514, scale $1: 24,000$.

Cemen, I., Wright, L.A., and Prave, A.R., 1999, Stratigraphy and tectonic implications of the latest Oligocene and early Miocene sedimentary succession, southernmost Funeral Mountains, Death Valley region, California, in Wright, L.A., and Troxel, B.W., eds., Cenozoic basins of the Death Valley region: Geological Society of America Special Paper 333, p. 65-86.

Cole, J.C., and Cashman, P.H., 1999, Structural relationships of preTertiary rocks in the Nevada Test Site region, southern Nevada: U.S. Geological Survey Professional Paper 1607, 39 p.

Cook, E.F., 1965, Stratigraphy of Tertiary volcanic rocks in eastern Nevada: Nevada Bureau of Mines and Geology Report 11, 61 p.

Cornwall, H.R., 1972, Geology and mineral deposits of southern Nye County, Nevada: Nevada Bureau of Mines and Geology Bulletin 77, 49 p., scale 1:250,000.

Cornwall, H.R., and Kleinhampl, F.J., 1961, Geologic map of the Bare Mountain quadrangle, Nevada: U.S. Geological Survey Geologic Quadrangle Map G0-157, scale 1:62,500.

D’Agnese, F.A., 2000, The Death Valley regional ground-water flow system (DVRFS): Increasingly complex problems, increasingly complex models [abs.]: Geological Society of America Abstracts With Programs, v. 32, no. 7, p. A-337.

D'Agnese, F.A., and Faunt, C.C., 1999, The Death Valley regional groundwater flow system (DVRFS) model calibration versus hydrogeologic conceptual model testing, in Slate, J.L., ed., Proceedings of conference on status of geologic research and mapping in Death Valley National Park, Las Vegas, Nevada, April 9-11, 1999: U.S. Geological Survey Open-File Report 99-153, p. 52-54.

Denny, C.S., 1965, Alluvial fans in the Death Valley region, California and Nevada: U.S. Geological Survey Professional Paper 466, 62 p., 5 plates, varying scales.

Denny, C.S., and Drewes, H., 1965, Geology of the Ash Meadows quadrangle, Nevada and California: U.S. geological Survey Bulletin 1181L, scale 1:250,000.

Drewes, H., 1963, Geology of the Funeral Peak quadrangle, California, on the east flank of Death Valley: U.S. Geological Survey Professional Paper 413, 78 p., 2 plates, scale 1:62,500.

Ekren, E.B., Anderson, R.E., Rogers, C.L., and Noble, D.C., 1971, Geology of northern Nellis Air Force Base Bombing and Gunnery Range, 
Nye County, Nevada: U.S. Geological Survey Professional Paper 651, $91 \mathrm{p}$.

Ekren, E.B., Bucknam, R.C., Carr, W.J., Dixon, G.L., and Quinlivan, W.D., 1976, East-trending structural lineaments in central Nevada: U.S. Geological Survey Professional Paper 986, 16 p.

Ekren, E.B., Rogers, C.L., and Dixon, G.L., 1973, Geologic and Bouguer gravity map of the Reveille Quadrangle, Nye County, Nevada: U.S. Geological Survey Miscellaneous Investigations Series Map I-806, scale 1:48,000.

Ekren, E. B., Orkild, P. P., Sargent, K. A., and Dixon, G. L., 1977, Geologic map of Tertiary rocks, Lincoln County, Nevada: U.S. Geological Survey Miscellaneous Investigation Series Map I-1041, scale 1:250,000.

Faunt, C.C., Belcher, W.R., and D'Agnese, F.A., 1999, Using geologic data for a three-dimensional hydrogeologic framework model of the Death Valley region, in Slate, J.L., ed., Proceedings of conference on status of geologic research and mapping in Death Valley National Park, Las Vegas, Nevada, April 9-11, 1999: U.S. Geological Survey Open-File Report 99-153, p. 59-60.

Fleck, R.J., and Carr, M.D., 1990, The age of the Keystone thrust: Laserfusion ${ }^{40} \mathrm{Ar} /{ }^{39} \mathrm{Ar}$ dating of foreland basin deposits, southern Spring Mountains, Nevada: Tectonics, v. 9, p. 467-476.

Fleck, R.J., Mattinson, J.M., Busby, C.J., Carr, M.D., Davis, G.A., and Burchfiel, B.C., 1994, Isotopic complexities and the age of the Delfonte volcanic rocks, eastern Mescal Range, southeastern California: Stratigraphic and tectonic implications: Geological Society of America Bulletin, v. 106, p. 1242-1253.

Gans, W.T., 1974, Correlation and redefinition of the Goodsprings Dolomite, southern Nevada and eastern California: Geological Society of America Bulletin, v. 85, p. 189-200.

Gardner, J.N., Eddy, A.C., Goff, A.C., Grafft, K.S., 1980, Reconnaissance geologic map of the northern Kawich and southern Reveille Ranges, Nye County, Nevada: University of California, Los Alamos Scientific Laboratory Map LA-8390, 1:62,500-scale.

Guth, P.L., 1980, Geology of the Sheep Range, Clark County, Nevada: Unpublished Ph.D. dissertation, Massachusetts Institute of Technology, Cambridge, Massachusetts, $189 \mathrm{p}$.

Guth, P.L., 1981, Tertiary extension north of the Las Vegas Valley shear zone, Clark County, Nevada: Geological Society of America Bulletin, v. 92, p. 763-771.

Hall, W.E., 1971, Geology of the Panamint Butte Quadrangle, Inyo County, California: U.S. Geological Survey Bulletin 1299, 67 p., scale 1:48,000.

Hall, W.E., and Stephens, H.G., 1963, Economic geology of the Panamint Butte quadrangle and Modoc District, Inyo County, California: California Division of Mines and Geology, Special Report 73, 39 p., 12 plates, scale 1:62,500.

Hay, R.L., Pexton, R.E., Teague, T.T., and Kyser, T.K., 1986, Spring-related carbonate rocks, Mg clays, and associated minerals in Pliocene deposits of the Amargosa Desert, California and Nevada: Geological Society of America Bulletin, v. 97, p. 1488-1503.

Heaman, L.M., and Grotzinger, J.P., 1992, 1.08 Ga diabase sills in the Pahrump Group, California: Implications for development of the Cordilleran miogeocline: Geology, v. 20, p. 637-640.

Hewett, D.G., 1931, Geology and ore deposits of the Goodsprings quadrangle, Nevada: U.S. Geological Survey Professional Paper $162,172 \mathrm{p}$.

Hillhouse, J.W., 1987, Late Tertiary and Quaternary geology of the Tecopa basin, southeastern California: U.S. Geological Survey Miscellaneous Investigations Series Map I-1728, scale 1:48,000.
Hunt, C.B., and Mabey, D.R., 1966, Stratigraphy and structure of Death Valley, California: U.S. Geological Survey Professional Paper 494-A, 160 p., scale 1:96,000.

Jayko, A.S., and Menges, C.M., 2001, A short note on developing digital methods for regional mapping of surficial basin deposits in arid regions using remote sensing and DEM data: Example from central Death Valley California, in Machette, M.N., Johnson, M.L., and Slate, J.L., eds., Quaternary and Late Pliocene geology of the Death Valley region: recent observations on tectonics, stratigraphy, and lake: U.S. Geological Survey Open-File Report 01-51, p. I167-I172.

Jayko, A.S., and Pritchett, D.W., 1999, Regional 1:100,000 mapping of Quaternary units from SPOT images and 30-m DEMs, in Slate, J.L., ed., Proceedings of conference on status of geologic research and mapping in Death Valley National Park, Las Vegas, Nevada, April 911, 1999, U.S. Geological Survey Open-File Report 99-153, p. 106.

Jennings, C.W., 1961, Geologic map of California-Kingman Sheet: California Division of Mines and Geology, scale 1:250,000.

Jennings, C.W., Burnett, J. L., and Troxel, B.W., 1962, Geologic map of California-Trona Sheet: California Division of Mines and Geology, scale 1:250,000.

Jennings, C.W., 1994, Fault activity map of California and adjacent areas, with locations and ages of recent volcanic eruptions: California Department of Conservation, Division of Mines and Geology, Geologic Data Map No. 6, scale 1:750,000.

Johnson, B.K., 1957, Geology of a part of the Manly Peak quadrangle, southern Panamint Range, California: University of California Publications in Geological Sciences, v. 30, no. 5, p. 353-424.

Johnson, J.G., Sandberg, C.A., and Poole, F.G., 1989, Early and Middle Devonian paleogeography of western United States, in McMillan, N.J., Embry, A.F., and Glass, D.J., eds., Devonian of the World: Calgary, Canadian Society of Petroleum Geologists, Memoir 14, v. 1, Regional synthesis, p. 161-182.

Kleinhampl, F.J. and Ziony, J.I., 1985, Geology of northern Nye County, Nevada: Nevada Bureau of Mines and Geology Bulletin 99A, plate A1A, scale 1:250,000.

Klinger, R.E., and Piety, L.A., 1996, Evaluation and characterization of Quaternary faulting on the Death Valley and Furnace Creek faults, Death Valley, California: Denver, Colorado, U.S. Bureau of Reclamation, Seismotectonics Report 96-10, 98 p.

Klinger, R.E., and Sarna-Wojcicki, A.M., 2001, Field trip guide for Day A, northern Death Valley, in Machette, M.N., Johnson, M.L., and Slate, J.L., eds., Quaternary and Late Pliocene geology of the Death Valley region: recent observations on tectonics, stratigraphy, and lake: U.S. Geological Survey Open-File Report 01-51, p. A5-A49.

Knott, J.R., 1998, Late Cenozoic tephrochronology, stratigraphy, geomorphology, and neotectonics of the western Black Mountains piedmont, Death Valley, California-implications for the spatial and temporal evolution of the Death Valley fault zone: Unpublished Ph.D. dissertation, University of California, Riverside, Cailfornia, $407 \mathrm{p}$.

Knott, J.R., 1999, Quaternary stratigraphy and geomorphology of Death Valley, in Slate, J.L., ed., Proceedings of conference on status of geologic research and mapping in Death Valley National Park, Las Vegas, Nevada, April 9-11, 1999: U.S. Geological Survey Open-File Report 99-153, p. 90-96.

Longwell, C.R., Pampeyan, E.H., Bowyer, B., and Roberts, R.J., 1965, Geology and Mineral Deposits of Clark County, Nevada: Nevada Bureau of Mines and Geology Bulletin 62, 218 p., scale 1:250,000.

Lundstrom, S.C, Mahan, S.A., Blakely, R.J., Paces, J.B., Dixon, G.L., and Young, O.D., in press, Geologic map of the Mound Spring 
quadarangle, Nye and Clark Counties, Nevada, and Inyo County, California: U.S. Geological Survey Miscellaneous Field Studies Map MF-2339, scale 1:24,000.

Lundstrom, S.C., Page, W.R., Langenheim, V.E., Young, O.D., Mahan, S.A., and Dixon, G.L, 1998, Geologic map of the Valley quadrangle, Clark County, Nevada: U.S. Geological Survey Open-File Report 98-508, scale 1:24,000.

Machette, M.N., 1985, Calcic soils of the southwestern United States, in, Weide, D.L., ed., Soils and Quaternary geology of the southwestern United States: Geological Society of America Special Paper 203, p. $1-21$.

Machette, M.N., Klinger, R.E., and Knott, J.R., 2001, Questions about Lake Manley's age, extent, and source, in Machette, M.N., Johnson, M.L., and Slate, J.L., eds., Quaternary and Late Pliocene geology of the Death Valley region: recent observations on tectonics, stratigraphy, and lake: U.S. Geological Survey Open-File Report 01-51, p. G143G149.

Machette, M.N., Martinez, C.N., Crone, A.J., Haller, K.M., and D'Addezio, G., 1999, Geologic and seismic hazards investigations of the Cow Creek area, Death Valley National Park, California: U.S. Geological Survey Open-File Report 99-155, 42 p., 2 plates.

Machette, M.N., Menges, C., Slate, J.L., Crone, A.J., Klinger, R.E., Piety, L.A., Sarna-Wojcicki, A.M., and Thompson, R.A., 2001, Field trip guide for Day B., Furnace Creek area, in Machette, M.N., Johnson, M.L., and Slate, J.L., eds., Quaternary and Late Pliocene geology of the Death Valley region: recent observations on tectonics, stratigraphy, and lake: U.S. Geological Survey Open-File Report 01-51, p. B51-B88.

Mackin, J.H., 1960, Structural significance of Tertiary volcanic rocks in southwestern Utah: American Journal of Science, v. 258, p. 81-131.

Maldonado, F., and Schmidt, D.L., 1990, Geologic map of the southern Sheep Range, Fossil Ridge, and Castle Rock area, Clark County, Nevada: U.S. Geological Survey Miscellaneous Investigations Series 1-2086, scale 1:24,000.

McAllister, J.F., 1952, Rocks and structure of the Quartz Spring area, northern Panamint Range, California: California Division of Mines and Geology Special Report 25, $38 \mathrm{p}$.

McAllister, J.F., 1956, Geology of the Ubehebe Peak quadrangle, California: U.S. Geological Survey Geologic Quadrangle Map GQ-95, scale $1: 62,500$.

McAllister, J.F, 1970, Geology of the Furnace Creek borate area, Death Valley, Inyo County, California: California Department of Conservation, Division of Mines and Geology, Map Sheet 14, 9 p., scale $1: 24,000$.

McAllister, J.F., 1974, Silurian, Devonian, and Mississippian formations of the Funeral Mountains in the Ryan quadrangle, Death Valley region, California: U.S. Geological Survey Bulletin 1386, $35 \mathrm{p}$.

McKee, Edwin H., 1985, Geologic map of the Magruder Mountain quadrangle, Esmeralda County, Nevada, and Inyo County, California: U.S. Geological Survey Geologic Quadrangle Map G0-1587, scale $1: 62,500$.

McKittrick, M.A., 1988, Surficial geologic map of the Nopah and Resting Spring ranges, Inyo County, California, and Nye County, Nevada: U.S. Geological Survey Miscellaneous Field Studies Map MF-1941, scale 1:62,500.
Menges, C.M., Taylor, E.M., Slate, J.L., and Dohrenwend, J.C., 1999, Strategy for mapping Quaternary surficial deposits in support of the Death Valley regional flow model in California and Nevada, in Slate, J.L., ed., Proceedings of conference on status of geologic research and mapping in Death Valley National Park, Las Vegas, Nevada, April 9-11, 1999, U.S. Geological Survey Open-File Report 99-153, p. $81-82$.

Menges, C.M., Taylor, E.M., Workman, J.B., Denning, P.A., San Juan, C., Grunwald, D.J., Jayko, A.J., and Dohrenwend, J.C., 2000, Surficial deposit mapping in support of the Death Valley Regional Flow System (DVRFS) ground-water model, California and Nevada [abs.]: Geological Society of America Abstracts with Programs, v.32, no. 7, p. A19.

Menges, C.M., Taylor, E.M., Workman, J.B., and Jayko, A.S., 2001, Regional surficial-deposit mapping in the Death Valley area of California and Nevada in support of ground-water modeling, in Machette, M.N., Johnson, M.L., and Slate, J.L., eds., Quaternary and Late Pliocene geology of the Death Valley region: recent observations on tectonics, stratigraphy, and lake: U.S. Geological Survey Open-File Report 01-51, p. H151-H166.

Miller, R.H., and Zilinsky, G.A., 1981, Lower Ordovician through Lower Devonian cratonic margin rocks of the southern Great Basin: Geological Society of America Bulletin, v. 92, p. 255-261.

Monsen, S.A., Carr, M.D., Reheis, M.C., and Orkild, P.P., 1992, Geologic map of Bare Mountain, Nye County, Nevada: U.S. Geological Survey Miscellaneous Investigations Series Map I-2201, 6 p., scale $1: 24,000$.

Moring, B., 1986, Reconnaissance geologic map of northern Death Valley, California and Nevada: U.S. Geological Survey Miscellaneous Field Studies Map MF-1770, scale 1:62,500.

Morrison, R.B., 1999, Lake Tecopa: Quaternary geology of Tecopa Valley, California, a multimillion-year record and its relevance to the proposed nuclear-waste repository at Yucca Mountain, in, Wright, L.A., and Troxel, B.W., 1999, eds., Cenozoic basins of the Death Valley region: Geological Society of America Special Paper 333, p. 301-343.

Nolan, T.B., 1924, Geology of the northwest portion of the Spring Mountains, Nevada: Unpublished Ph.D. dissertation, Yale University, New Haven, Connecticut, 125 p.

0'Brien, G.M., Jones, M.L., and Faunt, C.C., 1999, Development of a hydrogeologic database and data analysis tool for the Death Valley regional ground-water flow model, in Slate, J.L., ed., Proceedings of conference on status of geologic research and mapping in Death Valley National Park, Las Vegas, Nevada, April 9-11, 1999: U.S. Geological Survey Open-File Report 99-153, p. 61.

Osmond, J.C., 1962, Stratigraphy of the Devonian Sevy Dolomite in Utah and Nevada: American Association of Petroleum Geologists Bulletin, v. 46, p. 2033-2056.

Page, W.R., and Dixon, G.L., 1994, Modal analyses of selected Tertiary volcanic rocks from Nye and Lincoln counties, Nevada: U.S. Geological Survey Open-File Report 94-151, 69 p.

Page, W.R., Lundstrom, S.C., Harris, A.G., Workman, J.B., Mahan, S.A., Paces, J.B., Morgan, K.S., Kempton, E.C., Rowley, P.D., Langenheim, V.E., Dixon, G.L., Young, O.D., Burchfiel, B.C., Bell, J.W., and Smith, E.I., in press, Geologic Map of the Las Vegas $30 \times 60$-minute quadrangle, Clark and Nye Counties, Nevada, and Inyo County, California: U.S. Geological Survey Geologic Investigations Series, scale $1: 100,000$. 
Ponce, D.A., Blakely, R.J., Morin, R.L., and Mankinen, E.A., in press, Isostatic gravity map of the Death Valley groundwater model area, Nevada and California: U.S. Geological Survey Miscellaneous Field Studies Map MF-2381-C, scale 1:250,000.

Poole, F.G, Houser, F.N., and Orkild, P.P., 1961, Eleana Formation of the Nevada Test Site and vicinity, Nye County, Nevada: U.S. Geological Survey Professional Paper 424-D, p. D104-D111.

Potter, C.J., Dickerson, R.P., Sweetkind, D.S., Drake II, R.M., Taylor, E.M., Fridrich, C.J., San Juan, C.A., and Day, W.C., in press, Geologic map of the Yucca Mountain region, Nye County, Nevada: U.S. Geological Survey Miscellaneous Investigations Series Map I-2755, 123 p. text, scale 1:50,000.

Prave, A.R., and McMackin, M.R., 1999, Depositional framework of midto late Miocene strata, Dumont Hills and southern margin Kingston Range: Implications for the tectonostratigraphic evolution of the southern Death Valley region, in Wright, L.A., and Troxel, B.W., 1999, eds., Cenozoic basins of the Death Valley region: Geological Society of America Special Paper 333, p. 259-275.

Reheis, M.C., 1992, Geologic map of late Cenozoic deposits and faults in parts of the Soldier Pass and Magruder Mountain 15' quadrangles, Inyo and Mono Counties, California, and Esmeralda County, Nevada: U.S. Geological Survey Miscellaneous Investigations Series Map I2268, scale 1:24,000.

Reso, A., 1963, Composite columnar section of exposed Cenozoic and Paleozoic rocks in the Pahranagat Range, Lincoln County, Nevada: Geological Society of America Bulletin, v. 74, p. 910-918.

Ross, D.C., 1967, Generalized geologic map of the Inyo Mountains region, California: U.S. Geological Survey Miscellaneous Investigations Series Map I-506, scale 1:125,000.

Ross, R.J., Jr., 1964, Middle and Lower Ordovician formations in southernmost Nevada and adjacent California: U.S. Geological Survey Bulletin 1180-C, $101 \mathrm{p}$.

Rowley, P.D., Menhert, H.H., Naeser, C.W., Snee, L.W., Cunningham, C.G., Steven, T.A., Anderson, J.J., Sable, E.G., and Anderson, R.E., 1994 , Isotopic ages and stratigraphy of Cenozoic rocks of the Marysvale volcanic field and adjacent areas, west-central Utah: U.S. Geological Survey Bulletin 2071, 35 p.

Rowley, P.D., Nealey, David, Unruh, D.M., Snee, L.W., Mehnert, H.H., Anderson, R.E., and Gromme, C.S., 1995, Stratigraphy of Miocene ash-flow tuffs in and near the Caliente caldera complex, southeastern Nevada and southwestern Utah, in Scott, R.B., and Swadley, WC, eds., Geologic studies in the Basin and Range-Colorado Plateau transition in southeastern Nevada, southwestern Utah, and northwestern Arizona: U.S. Geological Survey Bulletin 2056, p. 47-88.

Sarna-Wocjicki, A.M., Machette, M.N., Knott, J.R., Klinger, R.E., Fleck, R.J., Tinsley, J.C, III, Troxel, B.W., Budahn, J.R., and Walker, J.P., 2001, Weaving a temporal and spatial framework for the late Neogene of Death Valley-Correlation and dating of Pliocene and Quaternary units using tephrochronology, ${ }^{40} \mathrm{Ar} /{ }^{39} \mathrm{Ar}$ dating, and other dating methods, in Machette, M.N., Johnson, M.L., and Slate, J.L., eds., Quaternary and Late Pliocene geology of the Death Valley region: recent observations on tectonics, stratigraphy, and lake: U.S. Geological Survey Open-File Report 01-51, p. E121-E135.

Sawyer, D.A., Fleck, R.J., Lanphere, M.A., Warren, R.G., Broxton, D.E., and Hudson, M.R., 1994, Episodic caldera volcanism in the Miocene southwestern Nevada volcanic field-Revised stratigraphic framework, ${ }^{40} \mathrm{Ar} /{ }^{39} \mathrm{Ar}$ geochronology, and implications for magmatism and extension: Geological Society of America Bulletin, v. 106, p. 13041318.
Scott, R.B., Gromme, C.S., Best, M.G., Rosenbaum, J.G., and Hudson, M.R., 1995a, Stratigraphic relationships of Tertiary volcanic rocks in central Lincoln County, southeastern Nevada, in Scott, R.B., and Swadley, W.C., eds., Geologic Studies in the Basin and Range-Colorado Plateau transition in southeastern Nevada, southwestern Utah, and northwestern Arizona: U.S. Geological Survey Bulletin 2056, p. 7-41.

Scott, R.B., Unruh, D.M., Snee, L.W., Harding, A.E., Nealey, David, Blank, H.R., Jr., Budahn, J.R., and Mehnert, H.H., 1995b, Relation of peralkaline magmatism to heterogeneous extension during the middle Miocene, southeastern Nevada: Journal of Geophysical Research, v. 100 , no. B6, p. 381-401.

Slate, J.L., Berry, M.E., Rowley, P.D., Fridrich, C.J., Morgan, K.S., Workman, J.B., Young, O.D., Dixon, G.L., Williams, V.S., McKee, E.H., Ponce, D.A., Hildenbrand, T.G., Swadley, WC, Lundstrom, S.C., Ekren, E.B., Warren, R.G., Cole, J.C., Fleck, R.J., Lanphere, M.A., Sawyer, D.A., Grunwald, D.J., Laczniak, R.J., Menges, C.M., Yount, J.C., and Jayko, A.S., 2000, Digital geologic map of the Nevada Test Site and vicinity, Nye, Lincoln, and Clark Counties, Nevada, and Inyo County, California: U.S. Geological Survey Open-File Report 99-554A, scale 1:100,000.

Snow, J.K., 1992, Large magnitude Permian shortening and continentalmarginal tectonics in the southern Cordillera: Geological Society of America Bulletin, v. 104, p. 80-105.

Snow, J.K, and Lux, D.R., 1999, Tectono-sequence stratigraphy of Tertiary rocks in the Cottonwood Mountains and northern Death Valley area, California and Nevada, in, Wright, L.A., and Troxel, B.W., 1999, eds., Cenozoic basins of the Death Valley region: Geological Society of America Special Paper 333, p. 17-64.

Stevens, C.H., Klingman, D.S., Sandberg, C.A., Stone, P., Belasky, P., Poole, F. G., and Snow, J. K., 1996, Mississippian stratigraphic framework of east-central California and southern Nevada with revision of Upper Devonian and Mississippian stratigraphic units in Inyo County, California: U.S. Geological Survey Bulletin 1988-J, 39 p.

Stewart, J.H., 1974, Correlation of uppermost Precambrian and lower Cambrian strata from southern to east-central Nevada: U.S. Geological Survey Journal of Research, v. 2, no. 5, p. 609-618.

Stewart, J.H., 1980, Geology of Nevada: A discussion to accompany the geologic map of Nevada: Nevada Bureau of Mines and Geology Special Publication 4, $136 \mathrm{p}$.

Stone, P., 1984, Stratigraphy, depositional history, and paleogeographic significance of Pennsylvanian and Permian rocks in the Owens Valley-Death Valley region, California: Ph.D. dissertation, Stanford University, Menlo Park, California, $399 \mathrm{p}$.

Stone, P., and Stevens, C.H., 1987, Stratigraphy of the Owens Valley Group (Permian), southern Inyo Mountains, California: U.S. Geological Survey Bulletin 1692, 19 p.

Stone, P., Stevens, C.H., and Magginetti, Robert T., 1987, Pennsylvanian and Permian stratigraphy of the northern Argus Range and Darwin Canyon area, California: U.S. Geological Survey Bulletin $1691,30 \mathrm{p}$.

Strand, R.G., 1967, Geologic map of California-Mariposa sheet: California Division of Mines and Geology, Sacramento, California, scale 1:250,000.

Streitz, R. and Stinson, M.C., 1974, Geologic map of California-Death Valley sheet: California Division of Mines and Geology, Sacramento, California, scale 1:250,000.

Taylor, G.C., 1993, Mineral land classification of the Ash Meadows, Big Dune, Eagle Mountain, Funeral Peak, Ryan, Pahrump, and Stewart 
Valley 15-minute quadrangles and High Peak 7.5-minute quadrangle, Inyo County, California: California Division of Mines and Geology Special Report 167, 39 p, scale 1:62,500.

Trexler, J.H., Jr., Cole, J.C., and Cashman, P.H., 1996, Middle DevonianMississippian stratigraphy on and near the Nevada Test site; Implications for hydrocarbon potential: American Association of Petroleum Geologists Bulletin, v. 80, p. 1736-1762.

Troxel, B.W., 1986, Pleistocene and Holocene deformation on a segment of the southern Death Valley fault zone, California, in Troxel, B.W., ed., Quaternary tectonics of southern Death Valley: Field Guide, Pacific Cell, Friends of the Pleistocene 1986 annual meeting, p. 13-16.

Troxel, B.W., and Butler, P.R., 1986a, Multiple Quaternary deformation, central part of the Confidence Hills, Death Valley, California: An example of folding along a strike-slip fault zone, in Troxel, B.W., ed., Quaternary tectonics of southern Death Valley: Field Guide, Pacific Cell, Friends of the Pleistocene 1986 annual meeting, p. 25-28.

Troxel, B.W., and Butler, P.R., 1986b, Time relations between Quaternary faulting, volcanism, and fan development, southern Death Valley, in Troxel, B.W., ed., Quaternary tectonics of southern Death Valley: Field Guide, Pacific Cell, Friends of the Pleistocene 1986 annual meeting, p. 31-35.

Tschanz, C.M. and Pampeyan, E.H., 1970, Geology and mineral deposits of Lincoln County, Nevada: Nevada Bureau of Mines and Geology Bulletin 73, 187 p., scale 1:250,000.

Vincellette, R.R., 1964, Structural geology of the Mount Stirling quadrangle, Nevada, and related scale-model experiments: Ph.D. dissertation, Stanford University, Menlo Park, California, 141 p.

Wagner, D.L., and Hsu, E.Y., 1987, Reconnaissance geologic map of parts of the Wingate Wash, Quail Mountains, and Manly Peak 15-minute quadrangles, Inyo and San Bernardino Counties, southeastern California: California Department of Conservation, Division of Mines and Geology Open-File Report 87-10, scale 1:62,5000.

Warren, R.G., Sawyer, D.A., Byers, F.M., Jr., and Cole, J.C., 1998, A petrographic/geochemical database and stratigraphic and structural framework for the southwestern Nevada volcanic field: NOAA National Geophysical Data Series, http://queeg.ngdc.noaa.gov/seg/ geochem/swnvf.

Webster, G.D., and Lane, N.R., 1967, The Mississippian-Pennsylvanian boundary in southern Nevada, in Teichert, Curt, and
Yochelson, E.L., eds., Essays in Paleontology and Stratigraphy, R. C. Moore Commemorative Volume: Lawrence, Kansas, Kansas University Press, Department of Geology Special Publication 2, p. 503-522.

Williams, P.L., 1967, Stratigraphy and petrology of the Quichapa Group, southwestern Utah and southeastern Nevada: Ph.D. dissertation, University of Washington, Seattle, Washington, $182 \mathrm{p}$.

Workman, J.B., Menges, C.M., Page, W.R., Ekren, E.B., Rowley, P.D., and Dixon, G.L., 2002, Tectonic map of the Death Valley groundwater model area, Nevada and California: U.S. Geological Survey Miscellaneous Field Studies Map MF-2381-B, scale 1:250,000.

Wright, L.A., Greene, R.C., Cemen, I., Johnson, F.C., and Prave, A.R., 1999a, Tectonostratigraphic development of the Miocene-Pliocene Furnace Creek Basin and related features, Death Valley region, California, in Wright, L.A., and Troxel, B.W., 1999, eds., Cenozoic basins of the Death Valley region: Geological Society of America Special Paper 333, p. 87-114.

Wright, L.A., Thompson, R.A., and Workman, J.B., 1999b, Tectonicgeologic map of the Death Valley region, California and Nevada, in Slate, J.L., ed., Proceedings of conference on status of geologic research and mapping in Death Valley National Park, Las Vegas, Nevada, April 9-11, 1999: U.S. Geological Survey Open-File Report 99-153, p. 73-74.

Wright, L.A., Thompson, R.A., and Workman, J.B., in press, Tectonicgeologic map of the Death Valley area, southeastern California: U.S. Geological Survey Geologic Investigations Series Map, scale $1: 250,000$.

Wright, L.A., and Troxel, B.W., 1984, Geology of the north $1 / 2$ of the Confidence Hills 15' Quadrangle, Inyo County, California: California Department of Conservation, Division of Mines and Geology, Map Sheet 34, 31 p., scale 1:24,000.

Wright, L.A., and Troxel, B.W., 1993, Geologic map of the central and northern Funeral Mountains and adjacent areas, Death Valley region, southern California: U.S. Geological Survey Miscellaneous Investigations Series Map I-2305, scale 1:48,000.

Wright, L.A., Troxel, B.W., Williams, E.G., Roberts, M.T., and Diehl, P.E., 1974, Precambrian sedimentary environments of the Death Valley region, eastern California and Nevada, in Geological Society of America, Guidebook: Death Valley region, California and Nevada [prepared for the 70th Annual Meeting of Cordilleran Section, Geological Society of America]: Shoshone, California, Death Valley Publishing Company, p. 27-35. 